\title{
Evaluation of stratocumulus cloud prediction in the Met Office forecast model during VOCALS-REx
}

\author{
S. J. Abel ${ }^{1}$, D. N. Walters ${ }^{1}$, and G. Allen ${ }^{2}$ \\ ${ }^{1}$ Met Office, Exeter, UK \\ ${ }^{2}$ University of Manchester, Manchester, UK
}

Received: 21 May 2010 - Published in Atmos. Chem. Phys. Discuss.: 7 July 2010

Revised: 1 November 2010 - Accepted: 8 November 2010 - Published: 10 November 2010

\begin{abstract}
Observations in the subtropical southeast Pacific obtained during the VOCALS-REx field experiment are used to evaluate the representation of stratocumulus cloud in the Met Office forecast model and to identify key areas where model biases exist. Marked variations in the large scale structure of the cloud field were observed during the experiment on both day-to-day and on diurnal timescales. In the remote maritime region the model is shown to have a good representation of synoptically induced variability in both cloud cover and marine boundary layer depth. Satellite observations show a strong diurnal cycle in cloud fraction and liquid water path in the stratocumulus with enhanced clearances of the cloud deck along the Chilean and Peruvian coasts on certain days. The model accurately simulates the phase of the diurnal cycle but is unable to capture the coastal clearing of cloud. Observations along the $20^{\circ} \mathrm{S}$ latitude line show a gradual increase in the depth of the boundary layer away from the coast. This trend is well captured by the model (typical low bias of $200 \mathrm{~m}$ ) although significant errors exist at the coast where the model marine boundary layer is too shallow and moist. Drizzle in the model responds to changes in liquid water path in a manner that is consistent with previous ship-borne observations in the region although the intensity of this drizzle is likely to be too high, particularly in the more polluted coastal region where higher cloud droplet number concentrations are typical. Another mode of variability in the cloud field that the model is unable to capture are regions of pockets of open cellular convection embedded in the overcast stratocumulus deck and an example of such a feature that was sampled during VOCALS-REx is shown.
\end{abstract}

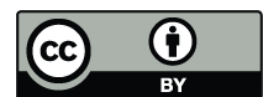

Correspondence to: S. J. Abel (steven.abel@metoffice.gov.uk)

\section{Introduction}

The prevalence of low level stratocumulus clouds over the global oceans (Klein and Hartmann , 1993) and their radiative effects have long been recognised as a key component of the Earth's climate system (Slingo , 1990). The response of these clouds to a changing climate is however highly uncertain and presents a large constraint on estimating climate sensitivity from models (Bony and Dufresene, 2005). For Numerical Weather Prediction (NWP) predicting the extent of stratocumulus cloud sheets can be of critical importance in the correct forecasting of visibility and surface temperatures. However, despite the importance of stratocumulus many general-circulation models (GCM's) struggle to accurately simulate these cloudy boundary layers (Ma et al., 1996; Siebesma et al., 2004; Hannay et al., 2009; Wyant et al., 2010). These problems are largely due to the difficulty in parameterizing a host of physical processes that interact to control the generation and evolution of stratocumulus. The general nature of these controlling processes has been wellestablished as a result of a number of previous observational studies, e.g. Turton and Nicholls (1987). Longwave radiative cooling at cloud top acts as a source of turbulent kinetic energy (TKE) driving the entrainment of dry environmental air from above the strong inversion at the top of the boundary layer. The result of this entrainment is to lift the cloud and maintain the balance with large-scale subsidence. It also generates eddies that penetrate through the depth of the boundary layer which act to maintain the supply of moisture from the sea surface to the cloud against its depletion from cloudtop entrainment. Shortwave radiative heating of the cloud layer during the day tends to reduce this generation of TKE at cloud-top, reducing the ability of turbulence to mix between the surface and the cloud. Ultimately, the cloud layer can become decoupled from the surface and the removal of the surface source of moisture leads to a thinning or break-up of the cloud during the day. The supply of moisture to the cloud

Published by Copernicus Publications on behalf of the European Geosciences Union. 
layer can also be modulated by drizzle which tends to peak towards the end of the night as the cloud depth (and hence the liquid water path) reaches a peak. Drizzle falling below the cloud layer acts as a sink of cloud water, further modulating the cloud-top radiation balance, and through evaporation can lead to a cooling of the sub-cloud layer and promote further decoupling. Both the cloud-top radiation balance and drizzle production are also susceptible to modulation by aerosols, specifically those that can act as cloud condensation nuclei and therefore act to modify cloud droplet number concentration and size (Twomey, 1974; Albrecht, 1989).

There have been significant advances in the representation of stratocumulus-topped boundary layers within the Met Office Unified Model, which is used for both climate prediction and NWP, since the introduction of the boundary layer scheme of Lock et al. (2000). This has the capacity to describe different vertical profiles of turbulent fluxes that occur in a number of different boundary layer types. Subsequent studies have described improvements to this approach, including refinements of the relationship between the cloudtop entrainment velocity and the longwave radiative cooling rate at cloud top (Lock, 2001, 2004). Lock (2004) and Siebesma et al. (2004) demonstrate that the Unified Model is able to simulate a realistic climatological mean stratocumulus deck over the north east subtropical Pacific Ocean. More recently Wyant et al. (2010) presented a model intercomparison study of stratocumulus in the southeast Pacific for the October 2006 period. They conclude that out of the fourteen participating modelling centres the ECMWF and Met Office forecast models show the greatest skill in cloud prediction. Whilst it is encouraging that the Unified Model has been shown to have some skill in the representation of stratocumulus the aim of this study is to highlight model shortcomings in order to identify key areas for further improvement. We do this by assessing model forecasts against a variety of observations from a recent major field experiment in the southeast Pacific. The VAMOS Ocean-Cloud-AtmosphereLand Study Regional Experiment (VOCALS-REx) was a large multi-national campaign that took place in October and November 2008 off the coast of Chile and Peru (Wood et al., 2010a). During the VOCALS-REx study period there were marked changes in the cloud topped boundary layer that were associated with large scale synoptic variability, a strong diurnal cycle in the stratocumulus, and other inhomogeneities in the cloud field such as pockets of open cellular convection (POCs) embedded in the surrounding overcast stratocumulus, a feature that is relatively common in this region (Wood et al., 2008). A correct representation of these inhomogeneities is an important diagnostic of a model's ability to describe correctly the range of physical processes which control the cloud layer.

The outline of this paper is as follows: Sect. 2 describes the setup of the Unified Model and presents some mean fields from the model simulations to give an overview of the salient features of the VOCALS-REx study region. A comparison of the model results with observations is then presented in Sect. 3. This section focuses on the model representation of the boundary layer structure and on variability in the cloud field during VOCALS-REx. Conclusions are then presented in Sect. 4.

\section{Model description and mean state}

\subsection{Model description}

The model used in this study is the NWP configuration of the Met Office Unified Model, run with a horizontal resolution of $0.15 \times 0.15$ degrees $(\sim 17 \mathrm{~km})$ over the VOCALS-REx area. Forecasts from this model configuration were used in support of the VOCALS-REx field experiment and the model is hereafter referred to as the MetUM. The horizontal grid comprises of 432 longitude by 300 latitude points with the model north pole rotated to $70^{\circ} \mathrm{N}, 85^{\circ} \mathrm{W}$ so that the grid is roughly isotropic over the VOCALS-REx region. The vertical grid comprises of 38 levels with a fixed lid at $39 \mathrm{~km}$. The vertical grid spacing is $20 \mathrm{~m}$ at the surface and increases with altitude, such that there are 10 model levels below $2 \mathrm{~km}$ (see filled circles in Fig. 2). The MetUM is run daily at 00:00 UTC to 2 days ahead for the 14 October to 19 November 2008 period and diagnostics output at hourly intervals. The model analyses are updated using a $6 \mathrm{~h}$ assimilation window from a three dimensional data assimilation (3D-Var) system (Lorenc et al., 2000). Lateral boundary conditions are taken from the global NWP model (cycle G48, operational from July to November 2008) at regular $3 \mathrm{~h}$ intervals and linearly interpolated for intermediate time steps.

The model physical parameterizations are similar to those used in the Met Office Hadley Centre atmospheric climate model HadGEM1 (Martin et al., 2006). The dynamical core is based on a non-hydrostatic two-time level semi-implicit, semi-Lagrangian formulation (Davies et al., 2005). The twostream radiation scheme of Edwards and Slingo (1996) is used in the MetUM and called hourly. The boundary layer scheme is a nonlocal eddy-diffusivity profile scheme that calculates the turbulent mixing driven from both surface sources and cloud-top (Lock et al., 2000; Lock, 2001, 2004). The scheme is coupled to an explicit boundary layer entrainment parameterization and mixes moist adiabatically conserved variables (a liquid/frozen water static energy and total water specific humidity) that are then decomposed into potential temperature, vapour and cloud liquid specific humidities using the Smith (1990) large-scale cloud scheme. The cloud scheme assumes a fixed triangular distribution of moisture around the grid-box mean value. When the grid-box mean relative humidity exceeds a critical threshold value, $\mathrm{RH}_{\text {crit }}$, then large-scale cloud is diagnosed. For the MetUM simulations the value of $\mathrm{RH}_{\text {crit }}$ varies as a function of height and is set to $91 \%$ at the surface and decreases to $80 \%$ at $1 \mathrm{~km}$ altitude and higher. The microphysics scheme is a modified 

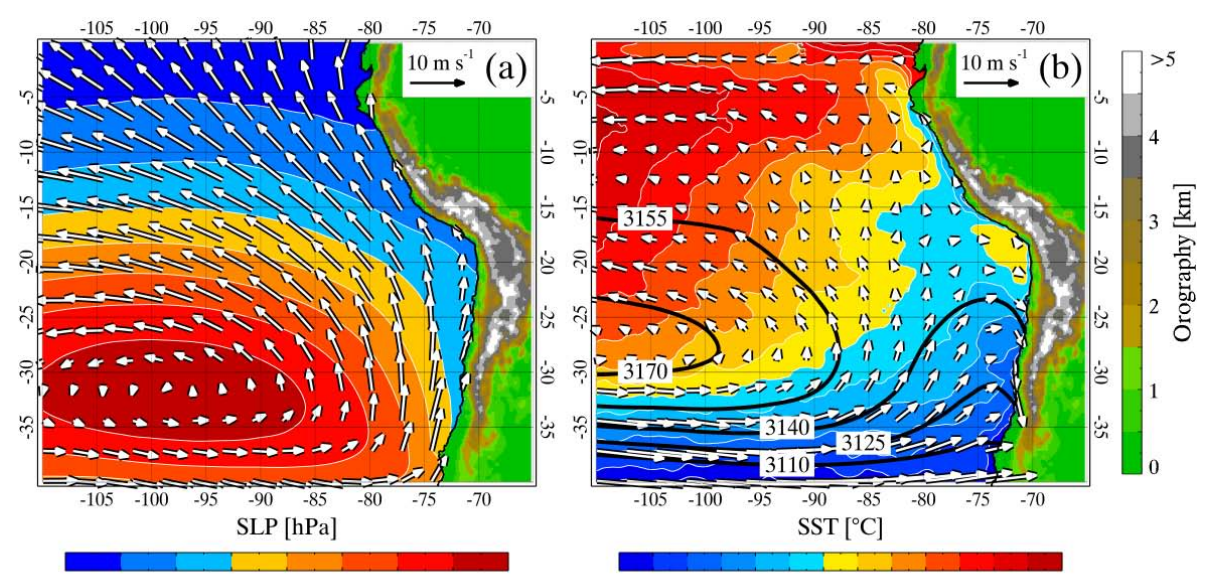

$\begin{array}{lllllllll}1012 & 1014 & 1016 & 1018 & 1020 & 1022 & 1024 & 1026 & 1028\end{array}$
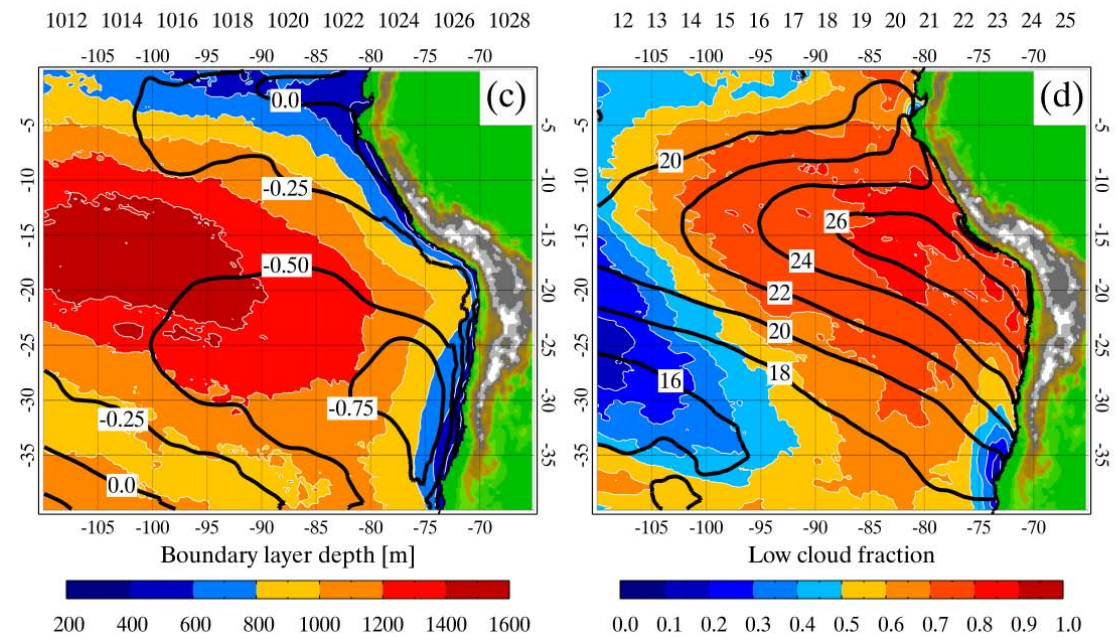

Fig. 1. Mean model fields for the period 14 October to 19 November 2008. The model orography is shown over land. (a) SLP (colours, hPa) with 10 metre wind arrows. (b) SST (colours, ${ }^{\circ} \mathrm{C}$ ) with $700 \mathrm{hPa}$ geopotential height (contours, m) and $700 \mathrm{hPa}$ wind arrows. (c) Boundary layer depth (colours, m) with $700 \mathrm{hPa}$ vertical velocity with a 4 degree latitude and longitude smoothing window applied (contours, $\mathrm{cm} \mathrm{s}^{-1}$ ). (d) Low cloud fraction (colours) with lower tropospheric stability (contours, ${ }^{\circ} \mathrm{C}$ ).

version of that described by Wilson and Ballard (1999). Differences that are relevant to stratocumulus clouds and drizzle production therein are described in more detail in Appendix A. A mass flux scheme is used to calculate transports from cumulus convection which is diagnosed from the mean humidity profiles and is explicitly coupled to the boundary layer scheme. If convection is triggered shallow and deep convective clouds are treated separately with different thermodynamic closures applied (see Martin et al. (2006) and references therein).

Data from the first $24 \mathrm{~h}$ of each 00:00 UTC model forecast are used in this study for comparison with observations in Sect. 3. The advantage of using short range forecasts in model evaluation studies is that the large-scale circulation is represented as accurately as possible within the context of a modern data assimilation system, allowing a less ambiguous attribution of model errors to deficiencies in parameterization schemes or missing physical processes.

\subsection{Time mean model fields}

A selection of model fields averaged over the time period of the simulations are shown in Fig. 1 to illustrate some of the salient features that are conducive to the formation of stratocumulus cloud in the southeast Pacific. Figure 1a shows the sea level pressure and $10 \mathrm{~m}$ winds. It is evident that the region is dominated by a high pressure system centred at $97^{\circ} \mathrm{W}$ and $32^{\circ} \mathrm{S}$ which is close to the climatological mean (Zuidema et al., 2009; Rahn and Garreaud, 2010b). The corresponding anticyclonic flow in combination with the blocking of zonal flow by the Andes mountain range (elevations $>5 \mathrm{~km}$ above sea level) leads to strong southerly winds along the western coast of South America, peaking at 8 to $9 \mathrm{~m} \mathrm{~s}^{-1}$ at $36^{\circ} \mathrm{S}, 74^{\circ} \mathrm{W}$ which is similar to the observed coastal jet at this location (Garreaud and Muñoz, 2005). This in turn drives oceanic upwelling that produces a tongue of cold sea surface temperatures along the coast as shown in Fig. 1b. As the surface winds reach the sharp change in the coastline at 
the southern end of Peru $\left(\sim 18^{\circ} \mathrm{S}\right)$, termed the Arica Bight, the wind speed drops off to $<3 \mathrm{~m} \mathrm{~s}^{-1}$ and there is a corresponding warmer sea surface temperature. Across the region as a whole the near surface winds tend to blow from colder to warmer surface temperatures, acting to increase the fluxes of latent and sensible heat into the marine boundary layer. Above the marine boundary layer at $700 \mathrm{hPa}$ the flow remains anticyclonic over much of the region although it turns poleward along the coast of Chile to the south of $20^{\circ} \mathrm{S}$ as shown from previous analyses of soundings during VOCALS-REx (Rahn and Garreaud, 2010a). To the south of the region there are strong westerlies that are often associated with the passage of transient mid-latitude synoptic scale features that can impact the southern end of the main stratocumulus deck.

Figure 1c shows the $700 \mathrm{hPa}$ vertical velocity, indicating the occurrence of large scale subsidence from the descending branch of the Hadley-Walker circulation throughout the majority of the region. This acts to maintain a strong temperature inversion at the top of the moist marine boundary layer. Also shown in Fig. 1c is the mean boundary layer height which is diagnosed from the models boundary layer scheme (see Fig. 1 of Lock et al. (2000) and Sect. 3.2). There is a steady increase in marine boundary layer height away from the coast with a broad maximum centred around $18^{\circ} \mathrm{S}, 100^{\circ} \mathrm{W}$. The boundary layer height in the Arica Bight is also significantly higher than the boundary layer top along the majority of the Chilean and Peruvian coastline. These features are in good agreement with satellite retrievals of cloud top height from October 2008 (Zuidema et al., 2009) although a cursory comparison suggests that there is a low bias in the model prediction of boundary layer height. This bias will be further explored in Sect. 3 .

Figure $1 \mathrm{~d}$ shows the mean static stability of the lower troposphere, calculated as the difference in the potential temperature at 700 and $1000 \mathrm{hPa}\left(\theta_{700}-\theta_{1000}\right)$, which has previously been used as a proxy to predict stratocumulus cloud cover e.g. Klein and Hartmann (1993). The high tropospheric stability values over the region are indicative of warmer air aloft and a strong temperature inversion at the top of the boundary layer. This combination of cool sea surface temperatures and descending warmer air above the boundary later results in a large and semi-persistent deck of stratocumulus cloud prevailing across the region. Also shown in Fig. $1 \mathrm{~d}$ is the associated low cloud cover in the model which has a broad maximum of 0.8 to 0.9 occurring between $75-$ $85^{\circ} \mathrm{W}$ and $10-20^{\circ} \mathrm{S}$. The low cloud cover tends to drop off westwards from the coast although there is a notable clearance in the coastal low cloud at $30-40^{\circ} \mathrm{S}$ that is associated with the strong subsidence and low boundary layer depths in the coastal jet shown in Fig. 1a and c. The general pattern of cloud cover is in good agreement with monthly mean satellite retrievals of cloud amount from October 2006 (Wyant et al., 2010). There is a strong correlation $(r=0.76)$ between the cloud fraction and the lower tropospheric stability when using the mean model fields depicted in Fig. 1.

\section{Model evaluation}

\subsection{Boundary layer structure}

A key component of the VOCALS-REx measurement strategy was to document the mean structure and variability of the cloud topped boundary layer along the $20^{\circ} \mathrm{S}$ latitude line out to about $86^{\circ} \mathrm{W}$. The $20^{\circ} \mathrm{S}$ line was repeatedly sampled at regular intervals throughout the field campaign between the 18 October and 15 November 2008, primarily by the NCAR C130 and FAAM BAe-146 research aircraft. Additional measurements were performed by the Ronald. H. Brown research vessel that included multiple soundings at four hour intervals and by other aircraft closer to the coast. There was also a coastal measurement site at Iquique $\left(20.2^{\circ} \mathrm{S}, 70.1^{\circ} \mathrm{W}\right)$ that launched radiosondes every four hours.

Figure 2 summarises the mean observed profiles of potential temperature, specific humidity and the zonal and meridional wind components at various points along the $20^{\circ} \mathrm{S}$ latitude line. Data are taken from all of the Ronald H. Brown soundings that lie within one degree of latitude and longitude from $85^{\circ} \mathrm{W}$ ( 20 sondes) and $75^{\circ} \mathrm{W}$ (47 sondes) during the period of the MetUM simulations. These correspond to the location of the Stratus buoy at $85^{\circ} \mathrm{W}$ which has routinely collected surface observations since October 2000 (Ghate et al., 2009) and has been a focus for observations from previous research cruises in the southeast Pacific (Bretherton et al., 2004; Serpetzoglou et al., 2008), and the SHOA Dart buoy at $75^{\circ} \mathrm{W}$. The data at $70^{\circ} \mathrm{W}$ are taken from all of the soundings released at Iquique during the VOCALS-REx campaign (187 sondes). Also included in Fig. 2 are the corresponding simulated profiles from the MetUM. At all three points the observed profiles show a strong capping inversion at the top of the boundary layer $>10^{\circ} \mathrm{C}$. Away from the near coastal region the MetUM marine boundary layer temperature is in good agreement with the observations but there is a notable cool bias at the coast. Above the inversion the MetUM profiles of potential temperature are in good agreement with the observations at all of the locations. The boundary layer depth is observed to increase to the West, with the inversion base (location of the minimum temperature in the mean profile) at approximately $0.9 \mathrm{~km}$ at the coast and $1.4 \mathrm{~km}$ at $85^{\circ} \mathrm{W}$. This trend is reproduced in the MetUM although there is a significant underestimate in the modelled inversion height at the coast. A smaller but still evident low bias in the MetUM inversion height is also apparent at $75^{\circ} \mathrm{W}$. Previous studies have shown that the inversion is located at similar heights in other years at $85^{\circ} \mathrm{W}$ although there is some inter-annual variability (Hannay et al., 2009; Zuidema et al., 2009; Wyant et al., 2010). The large underestimation in boundary layer height at the coast is common to many climate and forecast models (Wyant et al., 2010; Rahn and Garreaud, 2010a).

The specific humidity profiles show a moist boundary layer at all three points. At 70 and $75^{\circ} \mathrm{W}$ the moisture profile shows a weak decrease from the surface to the inversion base 

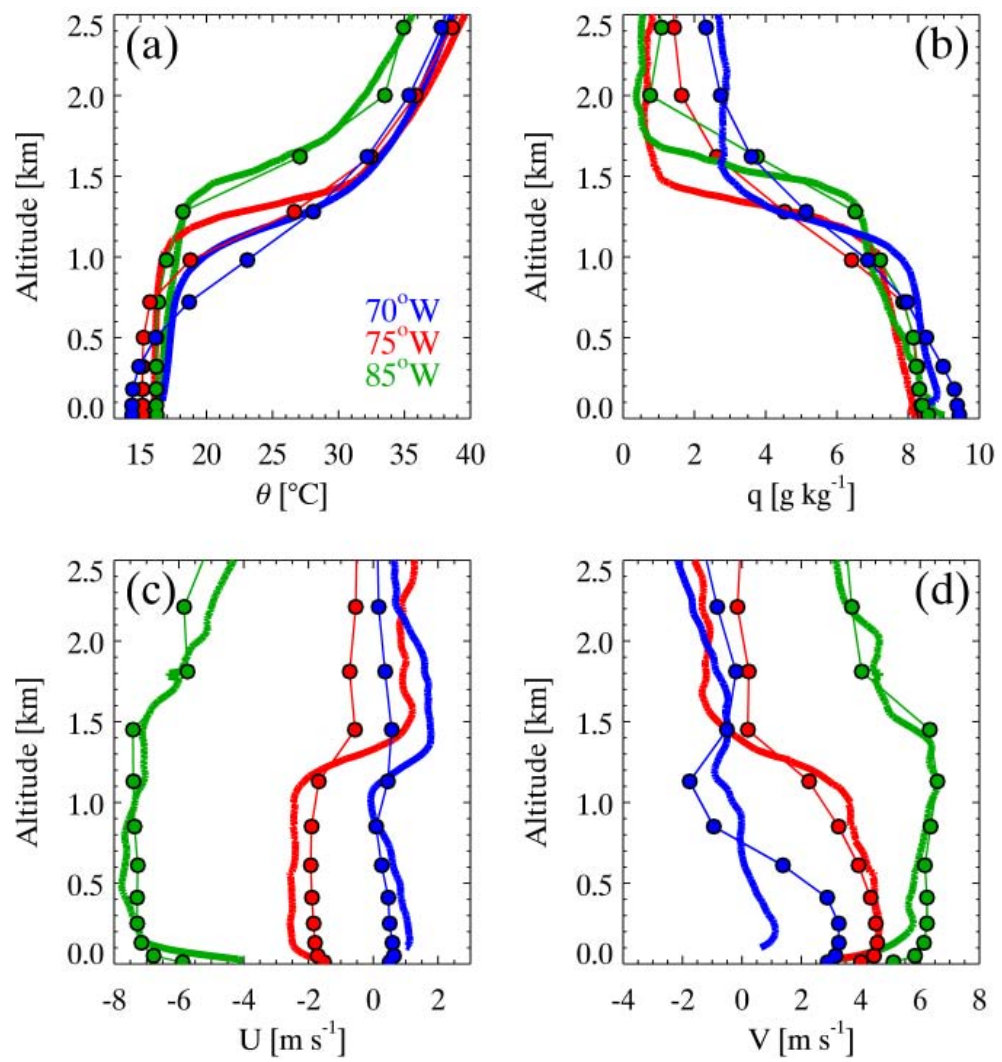

Fig. 2. Comparison of the mean measured (solid lines) and modelled (filled circles) profiles of (a) potential temperature, (b) specific humidity, (c) zonal wind and (d) meridional wind at various points along the $20^{\circ} \mathrm{S}$ latitude line. Observations at $75^{\circ} \mathrm{W}$ and $85^{\circ} \mathrm{W}$ are from the Ronald $\mathrm{H}$. Brown research vessel and at $70^{\circ} \mathrm{W}$ from Iquique.

which is typical of a fairly well mixed boundary layer. This is confirmed by the similarity between the observed mean lifting condensation level (LCL) of $0.8 \mathrm{~km}$ and the inversion base of $0.9 \mathrm{~km}$ at the coast. At the coast the MetUM has a boundary layer that is too shallow and moist. In contrast at $85^{\circ} \mathrm{W}$ the $\mathrm{LCL}$ is $0.7 \mathrm{~km}$ in both the observations and in the MetUM and the inversion base is $1.4 \mathrm{~km}$, indicating a more decoupled boundary layer. The specific humidity profile shows a stronger decrease with altitude from the surface to the LCL than from the LCL to the inversion base. Analysis of the MetUM forecast throughout the VOCALS-REx period suggests that along the $20^{\circ} \mathrm{S}$ latitude line the decoupling of the boundary layer is more common to the west of $77^{\circ} \mathrm{W}$ (not shown). This is associated with an increase in the occurrence of shallow cumulus clouds below the main stratocumulus deck in the model. Previous ship cruises in the southeast Pacific have shown evidence of decoupling at the Stratus buoy which often coincided with shallow cumulus clouds below the stratocumulus (Serpetzoglou et al., 2008), as have surface observations at San Felix Island $\left(26^{\circ} \mathrm{S}, 80^{\circ} \mathrm{W}\right.$ ) (Painemal et al., 2010). Evidence of boundary layer decoupling was also observed from aircraft observations during VOCALS-REx, particularly in regions away from the coast (Bretherton et al., 2010). The specific humidity profiles also show evidence of an increase in the moisture directly above the inversion near the South American coast in both the observations and the MetUM. Previous ship-based observations in the region have also observed enhanced moisture above the boundary layer that is associated with descending moist air that originates from the intertropical convergence zone (ITCZ) or from deep convection to the east of the Andes (Serpetzoglou et al., 2008). Allen et al. (2010) however present evidence from VOCALS-REx aircraft observations that show that in the near-coastal zone an increase in the specific humidity above the boundary layer is associated with lower concentrations of ozone. Ozone depleted air above the inversion suggests that there is a boundary layer source for the airmass as subsiding air from the free-troposphere is typically more ozone rich. Allen et al. (2010) propose that diurnal pumping of boundary layer air up the slope of the Andes can occur, and depending on the synoptic situation can then be advected out above the marine boundary layer inversion and subsequently entrained into the cloud layer itself.

The strength of the zonal and meridional wind components in the boundary layer are shown to increase from 70 to $85^{\circ} \mathrm{W}$ in Fig. $2 \mathrm{c}-\mathrm{d}$. At the coast the flow is fairly stagnant which is consistent with the blocking effect of the Andes topography. The MetUM forecast is in good agreement with 
the observed profiles in the boundary layer at 75 and $85^{\circ} \mathrm{W}$ but has a stronger southerly component at the coast. Above the boundary layer there is an onshore component of 1 to $2 \mathrm{~m} \mathrm{~s}^{-1}$ and a slight northerly wind out to $75^{\circ} \mathrm{W}$ which is consistent with the direction of the MetUM $700 \mathrm{hPa}$ winds in Fig. 1. However it is evident from the profiles that this onshore component is weaker in the MetUM. Further analysis of the Iquique profiles (not shown) shows a strong and recurrent diurnal signal in the onshore component above the boundary layer that reaches 4 to $5 \mathrm{~m} \mathrm{~s}^{-1}$ in the afternoon at $\sim 1.5 \mathrm{~km}$ and reduces to $\sim 0 \mathrm{~m} \mathrm{~s}^{-1}$ in the night. By early evening there is also an offshore component of $\sim 2 \mathrm{~m} \mathrm{~s}^{-1}$ at $3 \mathrm{~km}$ altitude. This circulation pattern is presumably driven by heating of the land during the day on the slopes of the Andes and whilst the change in the wind direction is captured by the MetUM, the strength of the diurnal cycle is underestimated which results in the weaker daily mean onshore wind shown in Fig. 2. The inability of the MetUM to represent the boundary layer structure at the coast may therefore be related to a poor representation of the mesoscale circulations around the Andes topography as is evident from the bias in the coastal winds. It is perhaps not surprising that the MetUM simulations do not accurately capture the coastal circulations when considering for example that the nearest land grid box to Iquique is $\sim 500 \mathrm{~m}$ above mean sea level which is approximately the height of the modelled marine boundary layer (Fig. 2 a). Simulating the flow across this land-sea boundary therefore presents significant challenges. A recent study by Wang et al. (2010) does shows a marked improvement in a model forecast of the coastal boundary layer structure that results from increasing the horizontal and vertical resolution of their model simulations, and attribute this improved model performance to a better representation of the coastal dynamics around steep topography.

\subsection{Cloud top height}

In addition to the soundings cloud top height observations from VOCALS-REx can also be used to assess the representation of the boundary layer depth in the MetUM as diagnosed by the boundary layer scheme. In stratocumulus capped boundary layers, the scheme calculates the height at which turbulent mixing from cloud top occurs through a two stage process. First the grid-level at the base of the capping inversion is found, either from the level of neutral buoyancy of a moist adiabatic parcel ascent from the surface layer in unstable surface conditions, or simply from the cloud fraction profile in stable surface conditions. Second, the inversion height is calculated by reconstructing a sub-grid profile using the cloud layer and free atmospheric lapse rates extrapolated into the inversion grid-level and assuming a discontinuous inversion structure (as described in Lock (2001)). As this diagnostic is representative of a cloud top height the model data are therefore screened for grid box low cloud fractions $>0.25$. We compare this diagnostic to cloud top height measurements made with the Wyoming cloud radar onboard the NCAR C-130 aircraft and with a downward pointing lidar on the NERC Do-228 aircraft.

Figure 3a shows the variability of cloud top height along the $20^{\circ} \mathrm{S}$ latitude line. The dark and light grey shading span the interquartile range and upper and lower deciles from the MetUM forecast during the whole VOCALS-REx period. The median is shown with a solid black line. The C-130 observations from all measurements made within one degree of latitude of $20^{\circ} \mathrm{S}$ are combined into two degree longitude bins. The observed median values are shown by the green circle and the interquartile range by the green error bars. As inferred from the sounding data there is a steady westward increase in the cloud top height from about $1.1 \mathrm{~km}$ at $71^{\circ} \mathrm{W}$ to $1.6 \mathrm{~km}$ at $85^{\circ} \mathrm{W}$. The MetUM cloud top height is typically lower with the median of the observations always above the 75th percentile of the model data. A sharp decrease in the model cloud top height is shown to occur between $71^{\circ} \mathrm{W}$ and the coast which is consistent with the bias shown in the comparison with the soundings at Iquique. Also highlighted in Fig. 3a are the two most extreme days shown in the aircraft observations. On the 18 October the cloud top height was approximately $1.1 \mathrm{~km}$ and exhibited little variability between 73 and $83^{\circ} \mathrm{W}$. By the 23 October the observations show a rapid increase in the cloud top from $1.2 \mathrm{~km}$ near the coast to $2.2 \mathrm{~km}$ at $85^{\circ} \mathrm{W}$. The transition from the 18 to 23 October coincides with an upper level disturbance and changes to the mean cloud cover (see Sect. 3.3). The corresponding averaged daily cloud top height from the MetUM for these dates is also shown for comparison. It is encouraging that the MetUM is able to capture the response of the boundary layer depth that is induced by synoptic variability. It is also clear that these days are atypical for the VOCALS-REx period as the variation in cloud top height with longitude for these days largely falls outside of the upper and lower deciles of the MetUM data, particularly west of $75^{\circ} \mathrm{W}$.

The cloud top height bias is further quantified in Fig. 4 which takes each aircraft measurement and calculates the cloud top height difference using model data from the nearest grid-box and model time-point. The histograms show that the model typically underestimates the cloud top height by $200 \mathrm{~m}$ although it should be noted that the eastern most data point from the aircraft data is at $70.9^{\circ} \mathrm{W}$. The bias from both aircraft is largely consistent even though the flights span different time periods and different longitude ranges and may in part result from the inability of the model vertical resolution to resolve the sharp inversion at the top of the boundary layer. The altitude range of 1130 to $1810 \mathrm{~m}$ spans the majority of observations of cloud top height but is represented by only two vertical levels in the model (although it should be noted that the cloud top height diagnostic from the boundary layer scheme is a sub-grid calculation), whereas temperature and moisture inversions of more than $10^{\circ} \mathrm{C}$ and $6 \mathrm{~g} \mathrm{~kg}^{-1}$ often occur over vertical distances less than 100 to $200 \mathrm{~m}$ as shown in Fig. 2. 

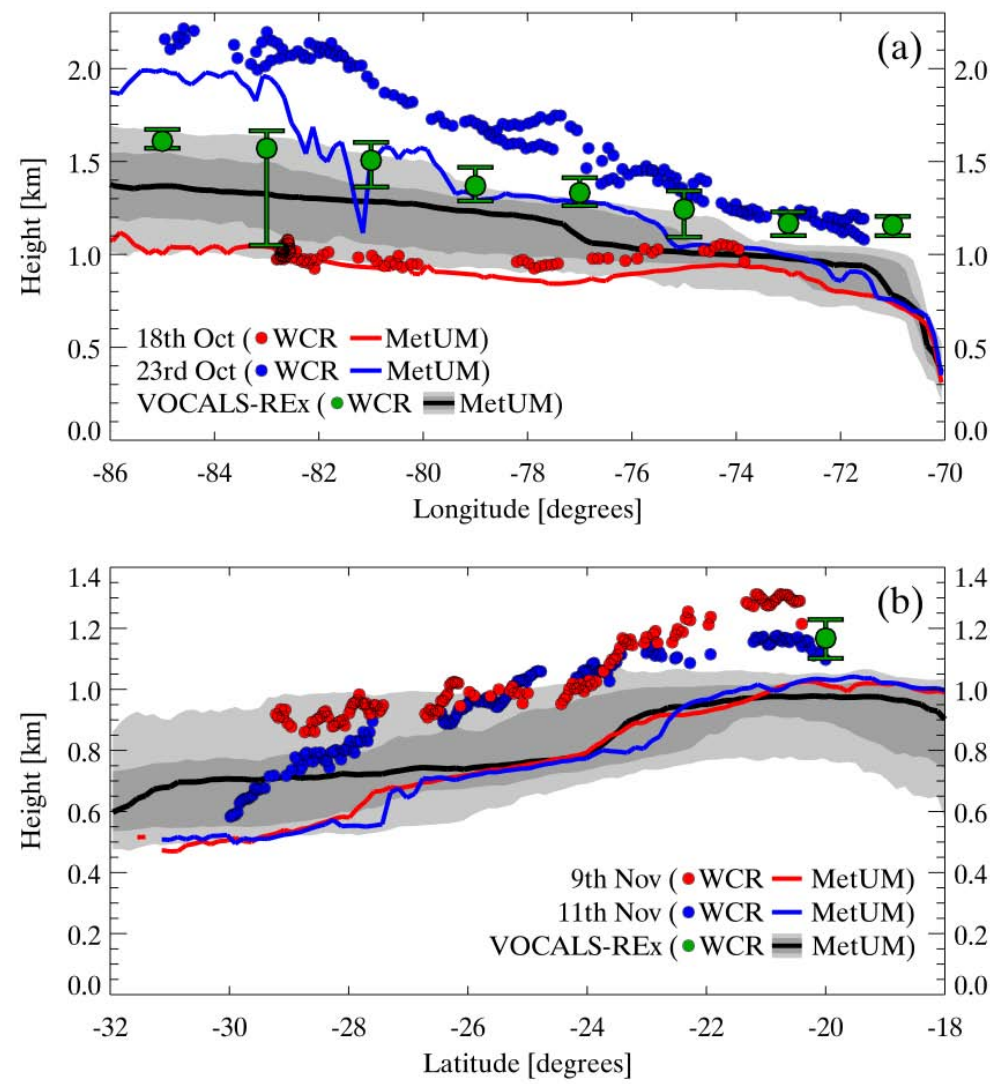

Fig. 3. Comparison of the measured and modelled cloud top height. The dark and lighter grey areas span the interquartile range and upper and lower deciles of the MetUM forecast data for the 14 October to 19 November 2008. The median of the MetUM data is shown with a solid black line. The green symbols and error bars show the median and interquartile range from all Wyoming cloud radar measurements made during the VOCALS-REx experiment. Panel (a) shows the variability along the $20^{\circ} \mathrm{S}$ latitude line. Observations and average daily MetUM data from the 18 and 23 October are highlighted in red and blue. Panel (b) shows the variability along the $73^{\circ} \mathrm{W}$ longitude line. Observations and average daily MetUM data from the 9 and 11 November are highlighted in red and blue.

The variability in cloud top height in the along shore direction is shown in Fig. 3b, with the statistics from the MetUM forecast taken along the $73^{\circ} \mathrm{W}$ longitude line. The cloud top height in the MetUM is about $1 \mathrm{~km}$ and fairly invariant in the Arica Bight region $\left(18-22^{\circ} \mathrm{S}\right)$, although this is lower than typical observed values by about $150 \mathrm{~m}$ at this point (compare with Fig. 3a). The boundary layer depth decreases to the south of this and is consistent with satellite and coastal observations during VOCALS-REx (Zuidema et al., 2009; Rahn and Garreaud, 2010a). At $32^{\circ} \mathrm{S}$ the median cloud top height in the model is $0.6 \mathrm{~km}$ and there is more day-to-day variability than at $20^{\circ} \mathrm{S}$. Whilst fewer aircraft observations were made in the along shore direction than on the $20^{\circ} \mathrm{S}$ latitude line, Fig. $3 \mathrm{~b}$ also includes cloud top height measurements made from two C-130 flights on the 9 and 11 November. The aircraft observations also show a decrease in the cloud top height to the south with slightly lower values on the 11 November. Whilst this trend is replicated in the MetUM, the low bias of about $200 \mathrm{~m}$ that was shown along $20^{\circ} \mathrm{S}$ is also evident.

\subsection{Daily variability of cloud fraction}

We now utilise observations from the GOES-10 geostationary satellite to document the variability in cloud amount during the VOCALS-REx period. We derive a low cloud cover product for the VOCALS-REx region over ocean using the GOES-10 channel 4 infrared radiances $(\lambda=10.7 \mu \mathrm{m})$ which are available approximately every 15 to $30 \mathrm{~min}$ at a horizontal resolution of $4 \mathrm{~km}$. The GOES-10 channel 4 data is not significantly affected by solar radiation, therefore allowing the application of a single retrieval algorithm during both the day and night. The radiances are initially converted to a brightness temperature (BT) and then simple thresholds applied to the pixel level data to discriminate between low clouds and colder high level clouds. For each GOES-10 pixel a cloud top temperature threshold function $T_{\text {thresh }}$ is calculated following

$T_{\text {thresh }}=\operatorname{SST}-\Gamma\left(z_{\mathrm{MBL}}+z_{\text {bias }}\right)$,

where $z_{\mathrm{MBL}}$ is the daily mean boundary layer depth in $\mathrm{km}$ and SST is the daily mean analysis of sea surface temperature 


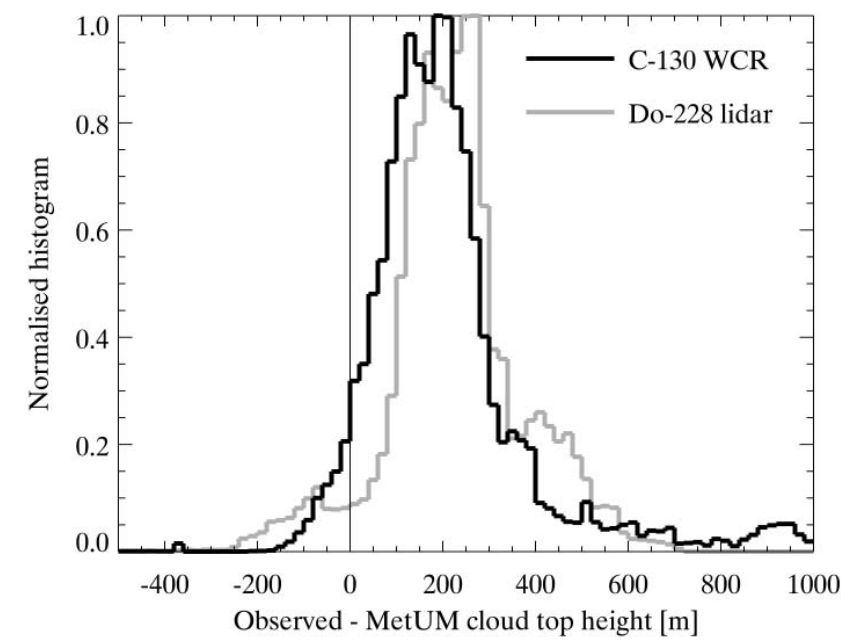

Fig. 4. Histogram of the difference between aircraft observations and the MetUM forecast of cloud top height along the $20^{\circ} \mathrm{S}$ latitude line.

in $\mathrm{K}$ from the MetUM. $z_{\text {bias }}$ is set at a value of $0.2 \mathrm{~km}$ to correct for the low bias in the MetUM $z_{\mathrm{MBL}}$ shown in Fig. 4. $\Gamma$ is the boundary layer temperature lapse rate in $\mathrm{K} \mathrm{km}^{-1}$ and is given by

$\Gamma=6.9+0.55\left(z_{\mathrm{MBL}}+z_{\text {bias }}\right)^{-1}$

which is derived from sounding observations measured under a variety of stratocumulus conditions during research cruises in the southeast Pacific (Zuidema et al., 2009). Each individual pixel is then classed as containing low or high cloud with the following thresholds

$$
\begin{array}{r}
T_{\text {thresh }}-10<\mathrm{BT} \leq \operatorname{MAX}\left[T_{\text {thresh }}, 284.5\right]: \text { low cloud } \\
\text { BT } \leq \operatorname{MAX}\left[T_{\text {thresh }}-10,270.0\right]: \text { high cloud }
\end{array}
$$

Utilisation of the channel 4 BT alone will not capture optically thin cirrus clouds and other spectral channels could be used to improve the identification of pixels containing high cloud. However, for this paper pixels identified as high cloud are only used as a flag to indicate the presence of overlying high cloud that may obscure any low cloud below. After the pixel classification individual pixels are aggregated onto a regular 0.25 degree grid and cloud fractions calculated. The low cloud fraction $\left(\mathrm{CF}_{\text {low }}\right)$ is then corrected for high cloud fraction $\left(\mathrm{CF}_{\text {high }}\right)$ using the random overlap assumption $\mathrm{CF}_{\text {low }}=\mathrm{CF}_{\text {low }} /\left(1-\mathrm{CF}_{\text {high }}\right)$. If $\mathrm{CF}_{\text {high }}>0.75$ then the grid-box is flagged as being contaminated by high cloud.

Figure 5a-b shows GOES-10 infrared images with the derived low cloud cover product along the $20^{\circ} \mathrm{S}$ latitude line from $70-95^{\circ} \mathrm{W}$ for the period of the model simulations. Figure 5a presents twice daily strips at 07:30 and 19:30 UTC taken from latitudes of $19.5-20.5^{\circ} \mathrm{S}$. The times are chosen to correspond to be close to the extremes of the diurnal cycle of cloud cover, liquid water path and precipitation as will be shown in Sect. 3.4. High cold clouds with a BT $<273 \mathrm{~K}$ are shaded in red and are relatively extensive from the 3 to 7 November. Figure 5b shows the corresponding GOES-10 low cloud cover retrieval at a time resolution of approximately $30 \mathrm{~min}$ where data is available. It is clear that there is a high degree of variability in the cloud during the VOCALSREx period, both on a day-to-day and on a diurnal timescale. For example there is extensive low cloud along the $20^{\circ} \mathrm{S}$ line from the 16 to 21 October. This period exhibits higher than average cloud amounts during the day time both in the coastal and remote maritime regions and coincides with the lowest observed boundary layer depth from the C-130 aircraft on the 18 October (Fig. 3). The low cloud is then more broken for several days from the 22 to 26 October. This corresponds with the rapid increase in the boundary layer height by the 23 October shown in Fig. 3 and is associated with the passage of an upper level disturbance (Rahn and Garreaud, 2010b) that is also evident in the MetUM simulations (not shown). Relatively stable conditions then persist for the beginning of November with a semi-regular diurnal cycle and significant day time clearing of low cloud from the coast. There is however a notable enhanced clearance of the coastal low cloud from the 15 to 16 November which coincides with a synoptically forced cut-off low, meridional convergence downstream of the coastal jet and reduced mid-tropospheric subsidence (Rahn and Garreaud, 2010b).

A time series of the GOES-10 and MetUM low cloud cover are shown in Fig. 5c-d for two longitude ranges along the $20^{\circ} \mathrm{S}$ latitude line. Figure $5 \mathrm{c}$ is averaged over $80-90^{\circ} \mathrm{W}$, an area that is centred on the Stratus buoy and typical of remote maritime conditions, whereas Fig. $5 \mathrm{~d}$ is averaged over $70-73^{\circ} \mathrm{W}$ and is more representative of the coastal cloud. In the remote maritime region it is evident that the variability in cloud cover on both diurnal and day-to-day timescales shown in the GOES-10 observations is captured very well with the MetUM (correlation coefficient, $r=0.76$ ). The mean cloud cover for the period is 0.86 for the GOES-10 retrieval and 0.78 for the MetUM. The lower value in the model is largely due to a slight underestimation in the night time maximum of cloud cover. Whilst the MetUM clearly has some skill in forecasting stratocumulus cloud amounts in the remote maritime region it exhibits much less skill in cloud prediction at the coast ( $r=0.33$ with GOES-10). It is particularly evident that the MetUM is unable to capture the large day time clearing of cloud cover that is shown to occur in the GOES-10 observations on certain days. The inability of the MetUM to represent this strong coastal clearing often leads to significantly higher day time cloud amounts than observed. It has already been shown if Fig. 2b that at the coastal site of Iquique the MetUM boundary layer is too moist. Further examination of the peak in the marine boundary layer relative humidity forecast by the MetUM shows that it is nearly always above the critical threshold value $\left(\mathrm{RH}_{\text {crit }}\right)$ that is used in the large-scale cloud scheme to diagnose cloud (as described in Sect. 2.1). This leads to the model being unable 

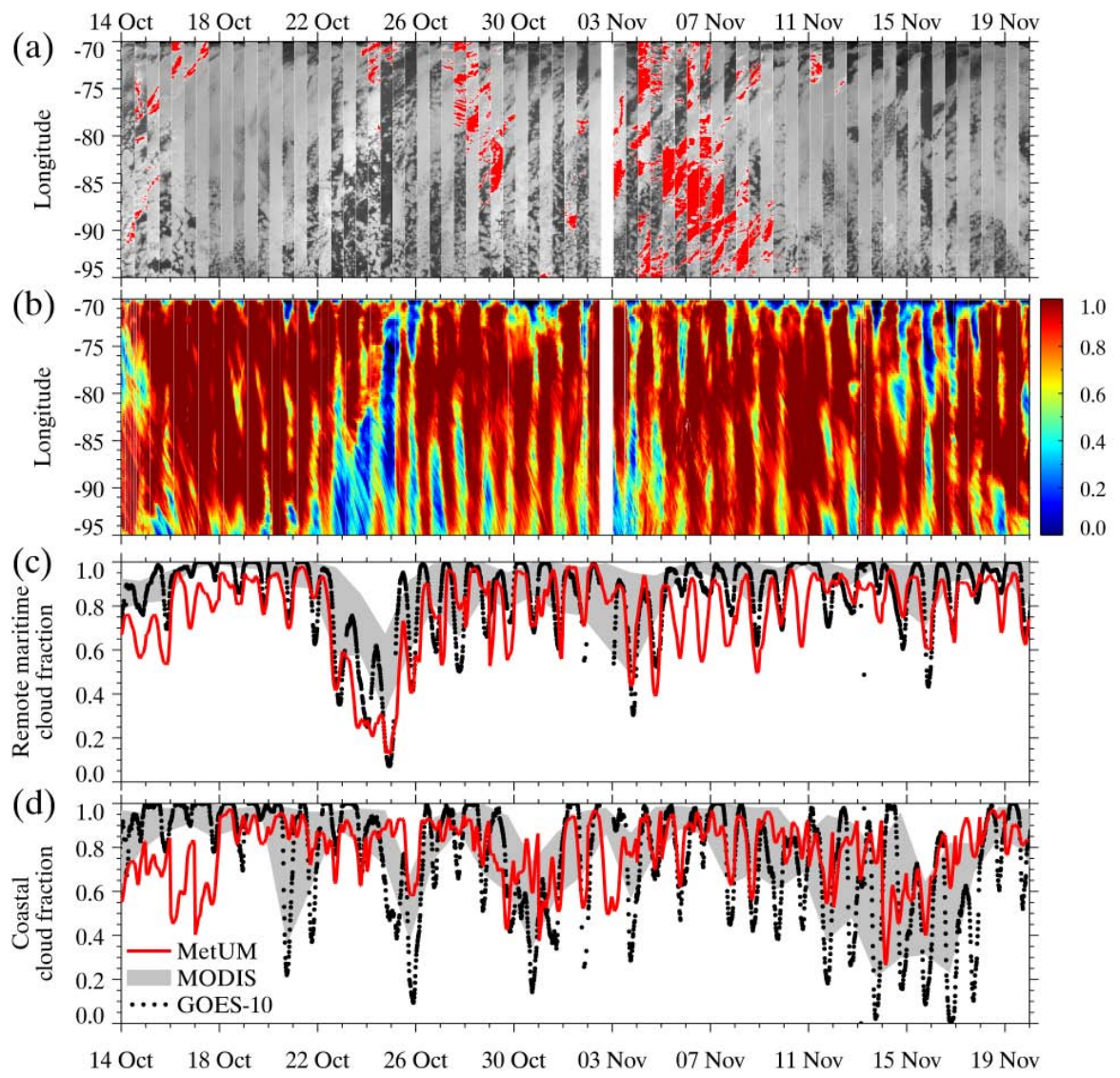

Fig. 5. Variability of low cloud cover along the $20^{\circ} \mathrm{S}$ latitude line from the 14 October to 19 November 2008. Panel (a) shows twice daily strips at $\sim$ 07:30 and 19:30 UTC of the channel 4 BT from GOES-10. High cold clouds with a BT $<273$ K are highlighted in red. Panel (b) shows a time-longitude plot of the GOES-10 low cloud fraction along $20^{\circ} \mathrm{S}$ derived from the channel 4 BT (data approximately every 30 min where available). Panels (c-d) compare the observed low cloud fraction from GOES-10 (black circles) and MODIS (grey band) with the MetUM forecast (red line) for the regions $80-90^{\circ} \mathrm{W}$ and $18-22^{\circ} \mathrm{S}$ in panel (c) and for $70-73^{\circ} \mathrm{W}$ and $18-22^{\circ} \mathrm{S}$ in panel (d).

to break-up the cloud layer at the coast sufficiently during the day time. It is interesting to note that the soundings at Iquique often show a marked diurnal cycle in the boundary layer relative humidity (not shown), with a drying out of the boundary layer during the day. This diurnal cycle is much weaker in the model simulations and may be related to an insufficient representation of the mesoscale coastal circulations as discussed in Sect. 3.1. At the coast the MetUM also suffers from the aforementioned small low bias in night time cloud amounts.

Also included in Fig. 5c-d are total cloud fraction observations from the spatially averaged $1 \times 1^{\circ}$ MODIS satellite level 3 version 5 data (Hubanks et al., 2008). The MODIS data are shown as a band that covers the observed range in cloud cover measured from all day and night time overpasses (maximum of 4 per day) from the polar orbiting Terra and Aqua satellites. The MODIS observations show the same trend in cloud cover through the period as GOES-10 in both the remote maritime and coastal regions. The degree of variability on certain days is a little higher in the GOES-10 data which may indicate that the diurnal cycle is not fully sampled by MODIS although differences between the retrievals may also be a contributory factor.

\subsection{Diurnal cycle of cloud and drizzle}

It is clear that in addition to the variability induced through changes in the large scale synoptic forcing throughout the VOCALS-REx period that there is a marked diurnal cycle in cloud cover. This diurnal cycle in the stratocumulus has been shown in previous studies at the Stratus buoy (Bretherton et al., 2004; Ghate et al., 2009) and through satellite observations of liquid water path (LWP) in the region (O'Dell et al., 2008). As commented on in the introduction the diurnal cycle is a result of the interaction between a range of physical processes that act to modify the boundary layer structure and cloud. The ability of the MetUM to capture this mode of variability is therefore a good test of the models boundary layer scheme. 


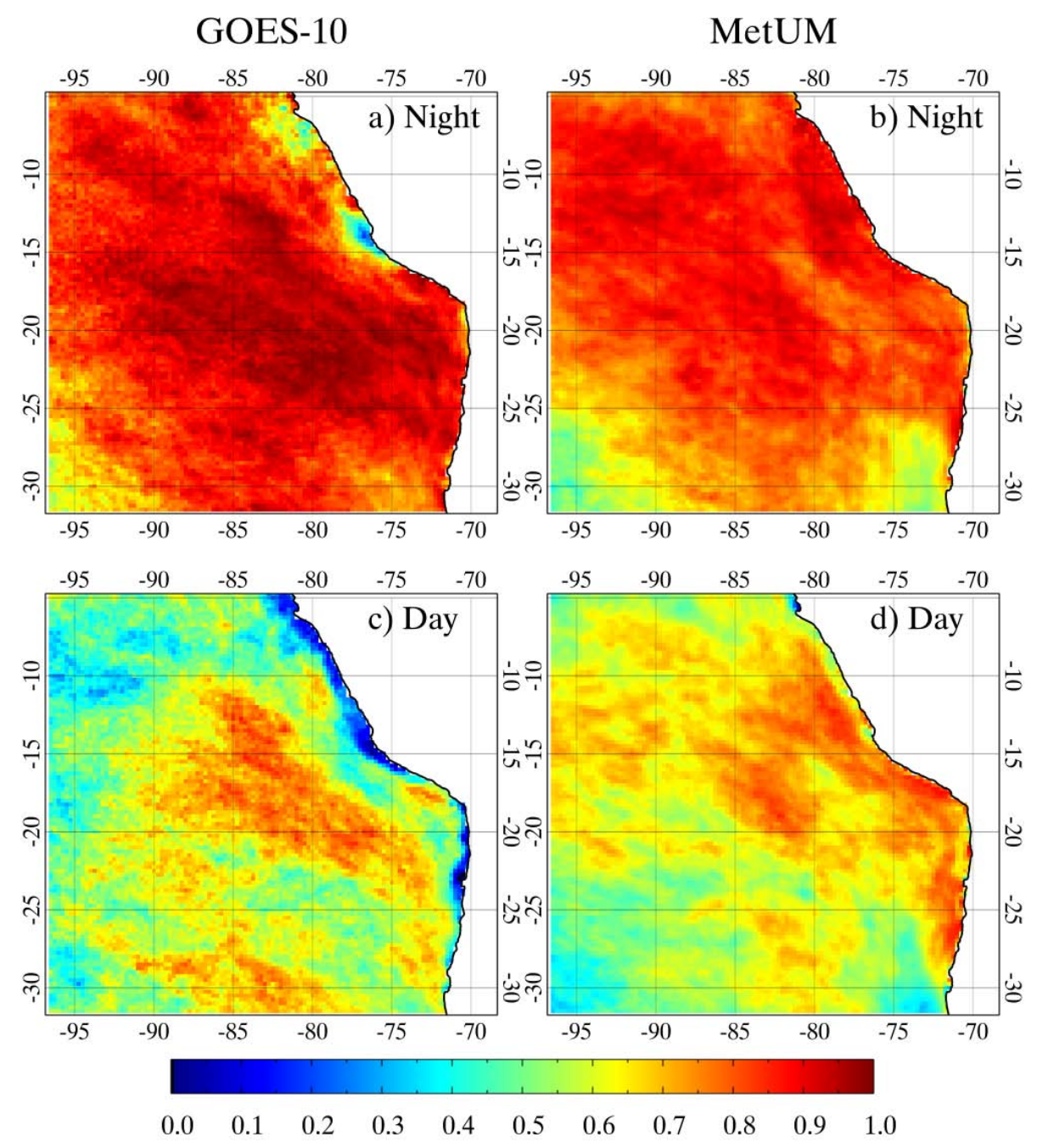

Fig. 6. Mean low cloud fraction at 07:30 UTC (night) and 19:30 UTC (day) for the period 14 October to 19 November 2008. GOES-10 data are shown in panels (a) and (c) and the MetUM forecast data in panels (b) and (d).

Figure 6 presents maps of the mean low cloud fraction during the VOCALS-REx period from GOES-10 and the MetUM at 07:30 and 19:30 UTC. These times are close to the maxima and minima of the diurnal cycle respectively. At night time the GOES-10 observations (Fig. 6a) show that large areas of the VOCALS-REx region have cloud fractions larger than 0.8 with a broad peak $>0.9$ orientated north-west to south-east from approximately $90^{\circ} \mathrm{W}, 15^{\circ} \mathrm{S}$ to $72.5^{\circ} \mathrm{W}$, $25^{\circ} \mathrm{S}$. This is broadly reproduced in the model (Fig. 6b) although the MetUM underestimates the peak night time values. Along the Peruvian coast the observations show a marked reduction in cloud at about $14^{\circ} \mathrm{S}$ which is coincident with the kink in the coastline and a further reduction at about $7^{\circ} \mathrm{S}$. Neither of these features are represented in the MetUM. To the southwest of the region both GOES-10 and the MetUM have lower cloud fractions which result from transient mid-latitude systems impacting the southern end of the stratocumulus deck. The MetUM also has lower cloud fractions in a region centred at $73^{\circ} \mathrm{W}, 30^{\circ} \mathrm{S}$ which corresponds to the exit region of the coastal jet (Garreaud and Muñoz, 2005). The GOES-10 observations do show a reduction in this area as well although to a lesser degree than the model. Twelve hours later there is a marked reduction in cloud amounts in both GOES-10 and the MetUM (Fig. 6c-d). The satellite observations show a strong coastal clearing of cloud along the majority of the Chilean and Peruvian coastline. An exception is in the Arica Bight area where the cloud is often more persistent during the day than in other coastal areas. It is evident that the MetUM is unable to represent this diurnal clearing of stratocumulus along the coast of South America but is able to capture the reduction in cloud in more remote maritime areas.

The corresponding maps of mean LWP for the VOCALSREx period are shown in Fig. 7. Observations are taken from the Advanced Microwave Scanning Radiometer (AMSR-E, v5 data) onboard the Aqua satellite (O'Dell et al., 2008), that 


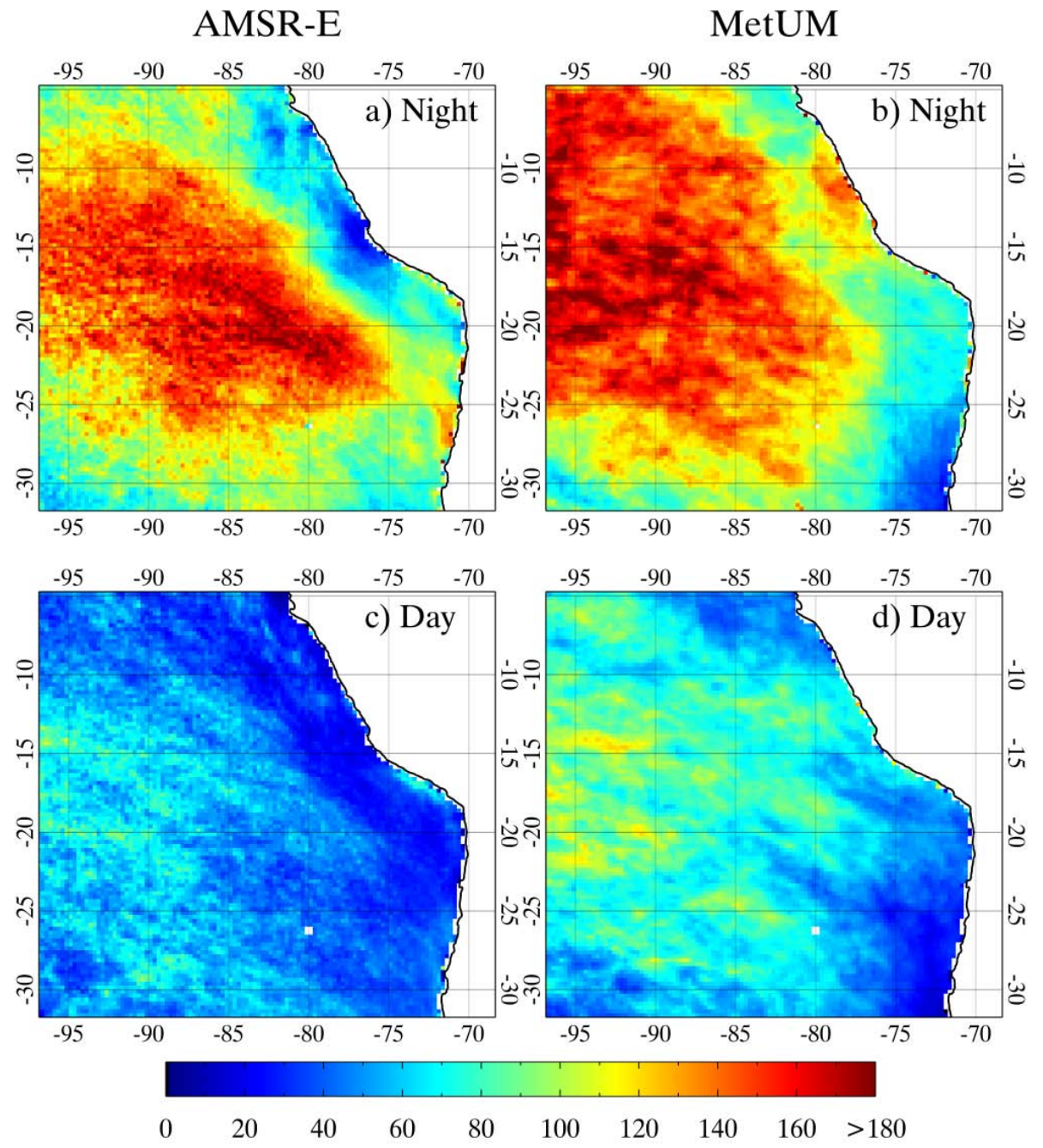

Fig. 7. Mean LWP $\left[\mathrm{g} \mathrm{m}^{-2}\right.$ ] at the time of the AMSR-E satellite descending (night) and ascending (day) passes for the period 14 October to 19 November 2008. The AMSR-E data are shown in panels (a) and (c) and the MetUM forecast data in panels (b) and (d).

has overpass times similar to those shown for cloud fraction in Fig. 6. The typical overpass times of the Aqua satellite are $\sim$ 07:00 and 19:00 UTC in the VOCALS-REx region. The night time AMSR-E data shows an increase in LWP away from the coast that is consistent with a deepening boundary layer and increased cloud thickness, with peak values in excess of $160 \mathrm{~g} \mathrm{~m}^{-2}$. Away from the coast and to the south of $10^{\circ} \mathrm{S}$ the MetUM is able to capture the spatial variability in LWP. In contrast to the north-west of $10^{\circ} \mathrm{S}$ the modelled LWP's are higher than observed by $\sim 40$ to $60 \mathrm{~g} \mathrm{~m}^{-2}$. Whilst not the focus of this study this may indicate that the transition between stratocumulus and the more open cellular convection typical in the trade-winds is not well captured in the model. There is a marked reduction in LWP during the day in both the observations and MetUM. Again away from the coast the spatial variability is well captured in the MetUM although the model typically overestimates the day time LWP. Along the coast of Peru there are areas of lower
LWP in the AMSR-E data during the day and night that coincide with the lower cloud amounts shown in the GOES-10 observations. As with cloud fraction these features are not captured in the MetUM.

The full diurnal cycle of cloud cover, LWP and drizzle is presented in Fig. 8 for the 14 October to 19 November period in two regions. The first region is centred on the location of the Stratus buoy $\left(18-22^{\circ} \mathrm{S}, 83-87^{\circ} \mathrm{W}\right)$ where the MetUM has been shown to have a fairly good representation of the stratocumulus topped boundary layer, and the second is from the near coastal region $\left(18-22^{\circ} \mathrm{S}, 70.5-74^{\circ} \mathrm{W}\right)$ where the model performance is significantly worse. In each region the diurnal cycle is calculated every day and the median and interquartile range presented reflects the variability in these daily mean values. An exception to this is the mean 2001 to 2005 October to November climatology of cloud fraction derived from radiometric surface measurements at the Stratus buoy (Ghate et al., 2009) which is included in Fig. 8a in 

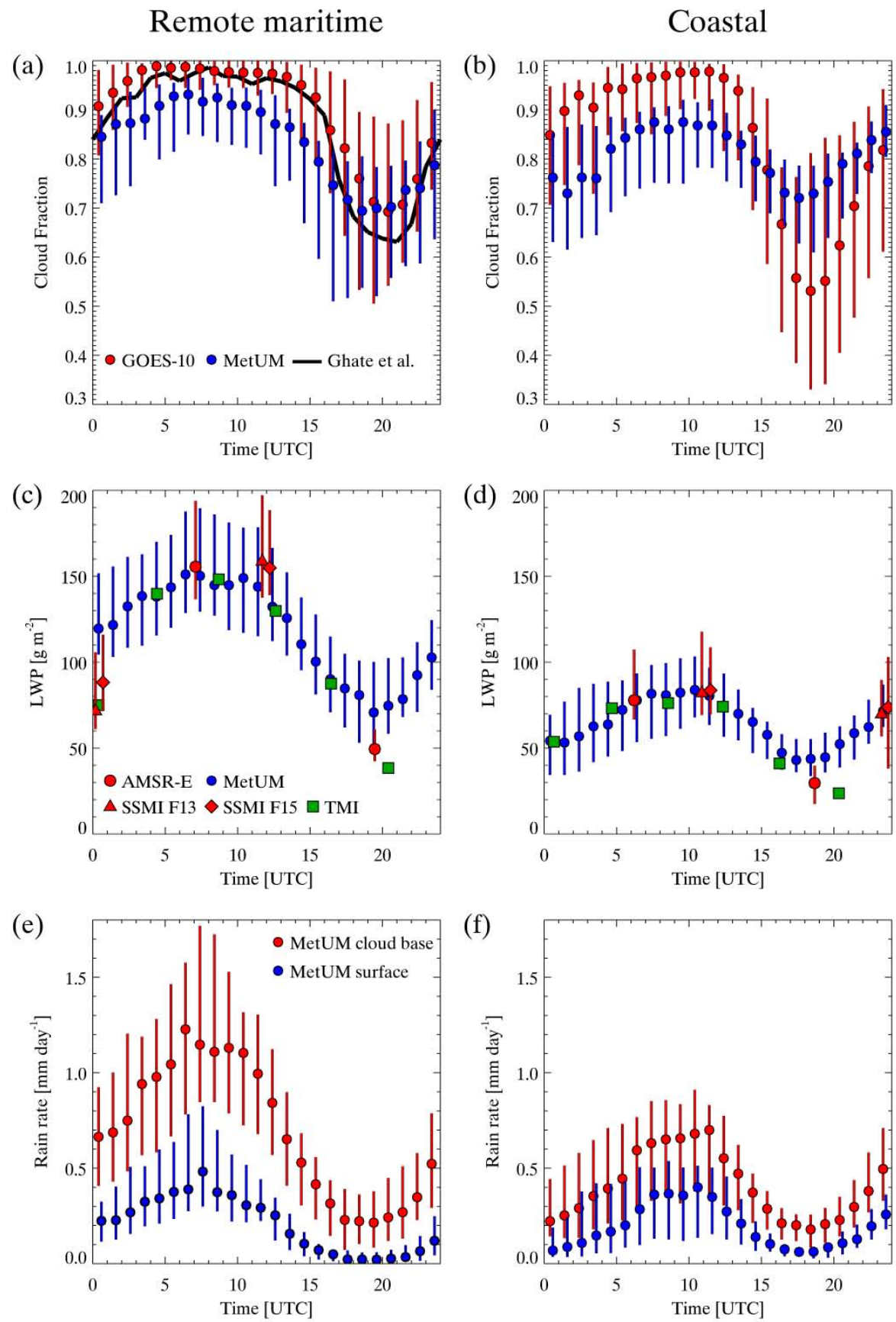

Fig. 8. Diurnal cycle of low cloud fraction, LWP and cloud base and surface rain rate for the period 14 October to 19 November 2008 . Panels (a), (c) and (e) are representative of a remote maritime region $\left(18-22^{\circ} \mathrm{S}, 83-87^{\circ} \mathrm{W}\right)$ and panels (b), (d) and (f) a coastal region $\left(18-22^{\circ} \mathrm{S}\right.$, $70.5-74^{\circ} \mathrm{W}$ ). The bars span the interquartile range and the median is shown by filled symbols. A mean 2001 to 2005 October to November climatology of cloud fraction from the STRATUS buoy (Ghate et al., 2009) is also shown in panel (a). For the TMI LWP data only the mean value is shown due to lower sampling statistics.

addition to the diurnal cycle from GOES-10 and the MetUM. For LWP in addition to the MetUM forecast and the AMSRE observations, data from the polar orbiting Special Sensor Microwave Imager (SSMI, v6 data) onboard the F13 and F15 satellites and from the semi-equatorial orbiting Tropi- cal Rainfall Measuring Mission (TRMM) Microwave Imager (TMI, v4 data) satellite (O'Dell et al., 2008) are also utilised. Unlike AMSR-E and SSMI the orbit of the TRMM satellite leads to different local overpass times on each day at the two locations. Whilst this gives additional information on the 
phase of the LWP diurnal cycle the statistics are poorer and so TMI observations are aggregated into 4 hourly time bins and the mean diurnal cycle calculated. The diurnal cycle of precipitation is shown both at cloud base and at the surface from the MetUM only.

In both regions there is a clear night time maximum and an afternoon minimum in cloud amount, LWP and drizzle (sunrise is $\sim 10: 30$ UTC and sunset at $\sim 23: 30$ UTC). The mean daily cloud fraction at the Stratus buoy from GOES$10 /$ MetUM is $0.90 / 0.83$ with a mean diurnal amplitude in cloud fraction (peak to trough) of $0.3 / 0.24$. The climatology of Ghate et al. (2009) is in good agreement with the satellite observations. It is clear that the lower daily mean diurnal amplitude in the MetUM results from an underestimation in the night time peak in cloud fraction by $\sim 0.05$ to 0.10 . The observations also show an increase in the variability as depicted by the larger interquartile range of cloud cover during the day time which is also captured in the model. At the coast the daily mean cloud cover from GOES-10/MetUM is $0.84 / 0.81$ with a mean diurnal amplitude of $0.45 / 0.15$. The agreement in the daily mean values at the coast is entirely fortuitous and it is clear that the MetUM has significantly higher cloud fractions during the day and lower cloud amounts at night. The observations show large variability in the amount of day time coastal clearing of cloud during the VOCALS-REx period e.g. the median value is 0.53 with an interquartile range of $0.33-0.81$ at 18:30 UTC. At the Stratus buoy night time LWP values typically reach $\sim 155 \mathrm{~g} \mathrm{~m}^{-2}$ although values up to $200 \mathrm{~g} \mathrm{~m}^{-2}$ are within the upper 75 th percentile of the data as shown from AMSR-E and both SSMI instruments. There is a significant decrease in LWP to $\sim 50 \mathrm{~g} \mathrm{~m}^{-2}$ at 19:30 UTC. The MetUM captures the diurnal maximum well but has a typical high day time bias of $\sim 20$ to $40 \mathrm{~g} \mathrm{~m}^{-2}$ when compared to the AMSR-E and SSMI data at the Stratus buoy. The TMI observations in combination with the other satellite data show that the MetUM is able to represent the phase of the diurnal cycle in LWP. In the coastal region the LWP diurnal range is $\sim 30$ to $75 \mathrm{~g} \mathrm{~m}^{-2}$. This is fairly well captured in the MetUM although as evident from the day-to-day variability shown by the interquartile range the MetUM often underestimates the night time LWP and overestimates the day time LWP which is consistent with the cloud fraction bias. It is also clear that larger biases exist in other locations along the coast of Chile and Peru as was shown in Fig. 7. Examination of the model data shows that away from the coast shallow cumulus below the stratocumulus are fairly common and typically contribute about $35 \%$ of the total LWP at the Stratus buoy. At the coast the frequency of occurrence of cumulus clouds is low and does not have a significant contribution to the total LWP.

The diurnal cycle of precipitation in the MetUM shows a strong correlation with LWP. At the Stratus buoy typical night time values of drizzle rate at cloud base are $\sim 1.1 \mathrm{~mm} \mathrm{day}^{-1}$, reducing to $\sim 0.25 \mathrm{~mm} \mathrm{day}^{-1}$ in the afternoon. The diurnal mean drizzle rate is $0.69 \mathrm{~mm} \mathrm{day}^{-1}$ at cloud base and $0.20 \mathrm{~mm} \mathrm{day}^{-1}$ at the surface. This is in good agreement with ship based estimates at the buoy in October 2001 of $0.7 \mathrm{~mm} \mathrm{day}^{-1}$ at cloud base (0.4 to $1.3 \mathrm{~mm} \mathrm{day}^{-1}$ uncertainty range) and $0.2 \mathrm{~mm} \mathrm{day}^{-1}$ at the surface $(0.1$ to $0.4 \mathrm{~mm} \mathrm{day}^{-1}$ uncertainty range) (Comstock et al., 2004). The uncertainty range in the observations arises from calibration uncertainties in the ship based radar. Bretherton et al. (2010) present C-130 aircraft observations of cloud-base and surface drizzle rates measured during VOCALS-REx. These are derived using both in-situ measurements of the drizzle drop size spectra and from application of the radar reflectivity to rain rate relations of Comstock et al. (2004) to measurements from a cloud radar. In the remote maritime region Bretherton et al. (2010) show that the typical drizzle rate is 1-2 $\mathrm{mm} \mathrm{day}^{-1}$ at cloud base and $0.05 \mathrm{~mm} \mathrm{day}^{-1}$ at the surface. These observations are weighted to the early morning which is close to the peak in the diurnal cycle of LWP and precipitation. This cloud base rain rate is again comparable to the MetUM simulations although the observed surface value is somewhat lower. In the coastal region the diurnal mean drizzle rate in the MetUM is $0.41 \mathrm{~mm} \mathrm{day}^{-1}$ at cloud base and $0.19 \mathrm{~mm} \mathrm{day}^{-1}$ at the surface. The aircraft observations of Bretherton et al. (2010) however show much lower drizzle rates $\left(\sim 0.1 \mathrm{~mm} \mathrm{day}^{-1}\right.$ at cloud base and negligible amounts at the surface), although it should be noted that the observations span various parts of the diurnal cycle from the early morning to mid afternoon. We examine the intensity of drizzle in the model in more detail in Sect. 3.5.

It is clear that the aircraft observations from VOCALSREx suggest that the vast majority of cloud base precipitation evaporates before reaching the surface $(\sim 95 \%$ in the remote maritime region shortly after sunrise for example). The MetUM shows a diurnal cycle in the evaporation rate of drizzle below cloud base, with $\sim 65 \%$ of the drizzle evaporated in the sub-cloud boundary layer at night and $90 \%$ during the day at the Stratus buoy. The increase in evaporation during the day is at least in part due to the drizzle drop size spectra shifting to smaller sizes at lower rain rates in the MetUM microphysics (see Appendix A). It is evident however that a larger fraction of drizzle reaches the surface in the model simulations as compared to the aircraft measurements of Bretherton et al. (2010). This may be related to the formulation of the rain drop fallspeed in the model (see Eq. A4), which is appropriate for rain drops $\sim 1-3 \mathrm{~mm}$ diameter but results in excessive fall speeds for small drizzle drops such as those that are typical in stratocumulus (Abel and Shipway, 2007). Using the more appropriate formulation of Abel and Shipway (2007) would increase the residence time of falling drizzle and consequently the amount of evaporation in the sub-cloud boundary layer. In the coastal region the amount of drizzle evaporation in the MetUM is lower than at the Stratus buoy (40\% at night and 60\% during the day). The larger fraction of cloud base drizzle reaching the surface is likely the result of both the boundary layer moisture being too high and the significant underestimation in the boundary layer depth at the 


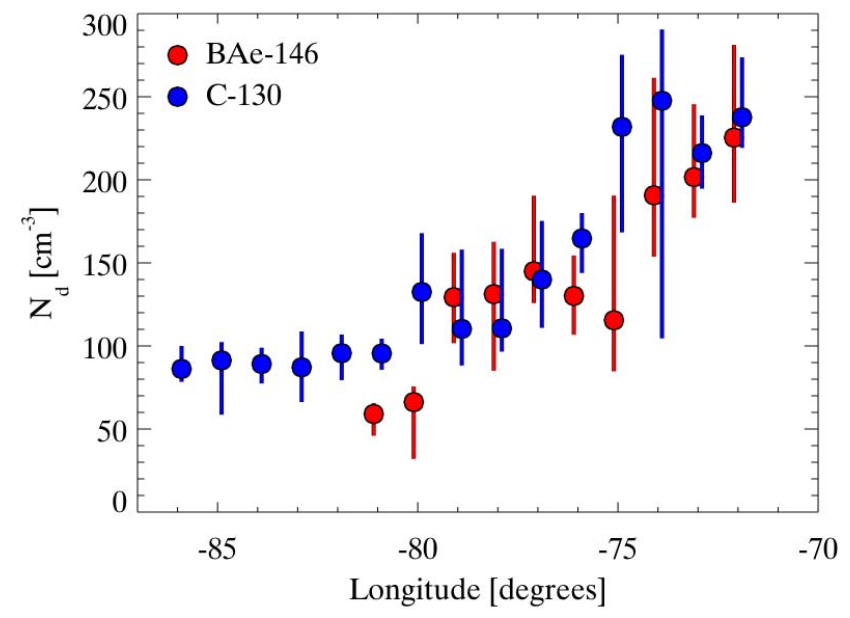

Fig. 9. Cloud droplet number concentration measured along the $20^{\circ} \mathrm{S}$ latitude line by the $\mathrm{C}-130$ and BAe- 146 research aircraft. The bars span the interquartile range and the median is shown by filled symbols.

coast (Fig 2), both of which will inhibit the amount of evaporation that can occur as drizzle falls below the cloud base.

\subsection{Drizzle efficiency}

Drizzle rates from stratocumulus are controlled by the macrophysical properties of the cloud such as LWP as shown in Fig. 8 and can be further modulated by microphysical variables such as cloud droplet number concentration, $N_{d}$, which is directly related to the available cloud condensation nuclei e.g. Shipway and Abel (2010). Previous aircraft closure studies suggest that the rain rate from stratocumulus shows a dependence on $L W P^{\alpha} / N_{d}$ where $\alpha$ ranges from 1.5 to $2(\mathrm{Ge}$ offroy et al., 2008). These sets of relations are largely consistent with idealised model simulations of warm rain production in stratocumulus clouds (Wood et al., 2009). In the southeast Pacific stratocumulus deck Comstock et al. (2004) use ship based radar to show that the rain rate at cloud base, $R_{\mathrm{CB}}$, is related to the cloud LWP and droplet number concentration following

$R_{\mathrm{CB}}=0.0156\left(\frac{\mathrm{LWP}}{N_{d}}\right)^{1.75}$

where $R_{\mathrm{CB}}$ is in $\mathrm{mm} \mathrm{hr}^{-1}$, LWP is in $\mathrm{g} \mathrm{m}^{-2}$ and $N_{d}$ is in $\mathrm{cm}^{-3}$. Aircraft observations from VOCALS-REx show significant variability in $N_{d}$ along the $20^{\circ} \mathrm{S}$ latitude line as shown in Fig. 9. Data are screened for cloud liquid water contents $>0.2 \mathrm{~g} \mathrm{~m}^{-3}$ and for a latitude range of 19.8 to $20.2^{\circ} \mathrm{S}$. The observations show that in the more polluted coastal region the typical $N_{d}$ is $\sim 250 \mathrm{~cm}^{-3}$. $\quad N_{d}$ gradually drops off away from the coast as the airmass becomes cleaner with values of $\sim 90 \mathrm{~cm}^{-3}$ at $85^{\circ} \mathrm{W}$. This transition from a more polluted coastal to a clean maritime regime

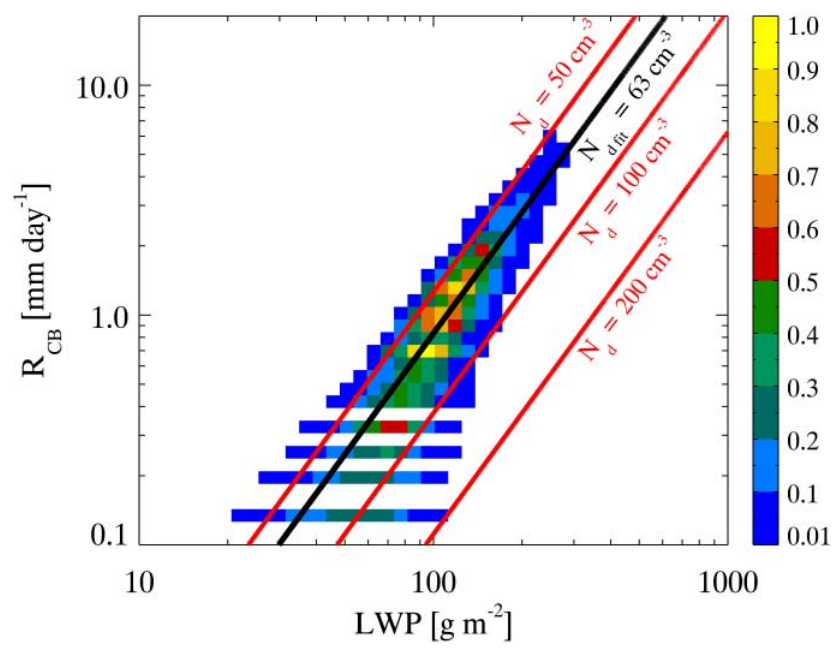

Fig. 10. Histogram of rain rate at cloud base as a function of LWP. The histogram is normalised so that the peak value is 1.0. Data are taken from the MetUM forecast from 14 October to 19 November 2008 in the region $15-25^{\circ} \mathrm{S}$ and $80-90^{\circ} \mathrm{W}$. The red lines show the Comstock et al. (2004) relation for cloud droplet number concentrations of 50,100 and $200 \mathrm{~cm}^{-3}$. The black line is a fit to the MetUM data.

along $20^{\circ} \mathrm{S}$ is also evident in aerosol physical and chemical measurements made during VOCALS-REx (Allen et al., 2010). The microphysics in the MetUM however use a fixed $N_{d}$ of $100 \mathrm{~cm}^{-3}$ over the ocean and so the model is unable to respond to these variations in cloud droplet number concentration.

Figure 10 shows how $R_{\mathrm{CB}}$ varies with LWP in the MetUM and also includes the relation from Comstock et al. (2004) for $N_{d}$ values of 50,100 and $200 \mathrm{~cm}^{-3}$. Equation 4 is appropriate for length scales of about $75 \mathrm{~km}$ and so a smoothing window of four grid boxes is applied to the model data for comparison. It is evident that the model drizzle rate response to an increase in LWP is of a similar form to that derived from the ship based observations. However applying a fit of Eq. 4 to the model data suggests that the model response is more typical of a cloud with a $N_{d}$ of $63 \mathrm{~cm}^{-3}$ rather than the fixed value of $100 \mathrm{~cm}^{-3}$ used in the microphysics scheme. This suggests that the microphysics scheme in the model is too efficient in producing drizzle over ocean areas i.e. by a factor of $\sim(100 / 63)^{1.75}=2.24$. It can also be inferred that the drizzle rates in the more polluted airmass at the coast as shown in Fig. 8f are significantly overestimated, as was discussed in Sect. 3.4 in relation to the aircraft observations of Bretherton et al. (2010).

Previous analysis of the MetUM has also suggested that the intensity of drizzle is too high in both the operational forecast model (Bodas-Salcedo et al., 2008) and in singlecolumn versions of the model (Wyant et al., 2007), indicating that this bias is also typical of MetUM simulations in other stratocumulus regions. The production of drizzle in 

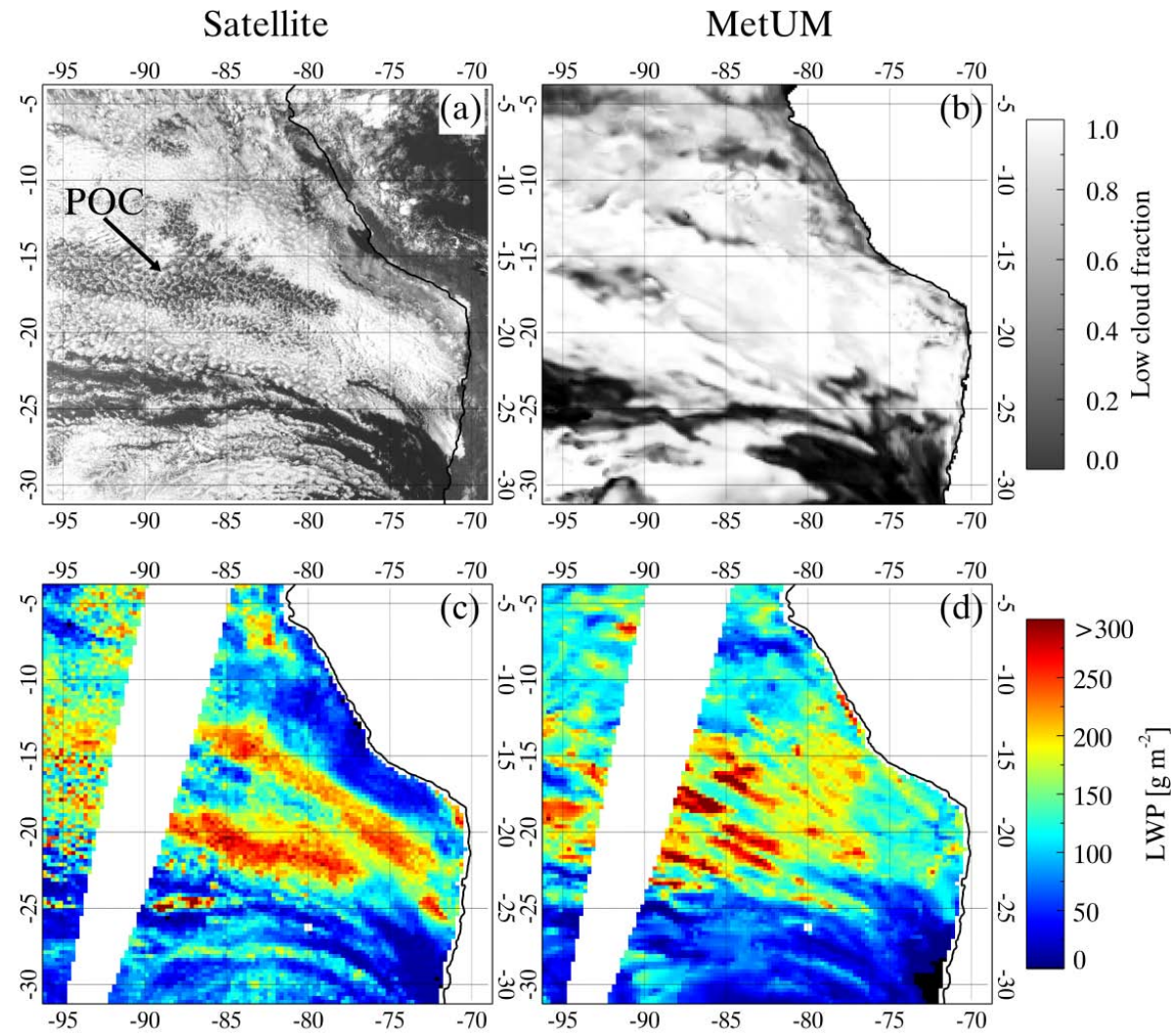

Fig. 11. An example of a POC type feature on the 28 October 2008. Panel (a) shows GOES-10 visible imagery at 12:45 UTC. A composite of night time satellite LWP observations from AMSR-E, SSMI F13 and SSMI F15 is shown in panel (c). The corresponding MetUM low cloud fraction and LWP are shown in panels (b) and (d).

the model due to the coalescence of cloud droplets is parameterized through an autoconversion scheme that controls the rate at which cloud water is converted to rain (see Appendix A). This parameterization is based on Tripoli and Cotton (1980) and has been shown to significantly overestimate the autoconversion rate in stratocumulus clouds and that other parameterizations better represent observations (Wood, 2005). Future work will look to explore the sensitivity of the MetUM drizzle efficiency to simulations that utilise different autoconversion parameterizations. Planned analysis of C-band radar and cloud radar observations from the Ronald H. Brown during VOCALS-REx (S. Yuter, personal communication, 2010) would then enable a more robust evaluation of the model.

\subsection{Pockets of Open Cells}

As mentioned in the introduction another mode of variability in cloud cover that is often observed in the southeast Pacific stratocumulus deck is pockets of open cells (POCs) embedded in regions of more overcast stratocumulus. An example of a POC type feature on the 28 October 2008 is shown in Fig. 11. The GOES-10 visible imagery at 12:45 UTC in Fig. 11a shows a large area (order several $1000 \mathrm{~km}$ ) of bro- ken cloud with open mesoscale cellular characteristics that is approximately orientated along an axis from $16^{\circ} \mathrm{S}, 95^{\circ} \mathrm{W}$ to $18^{\circ} \mathrm{S}, 78^{\circ} \mathrm{W}$. This open cellular region is surrounded by more overcast stratocumulus with relatively high LWP's $\left(>250 \mathrm{~g} \mathrm{~m}^{-2}\right)$ as shown by a night time composite of satellite observations from AMSR-E and SSMI in Fig. 11b. The eastern edge of this POC was sampled by both the C-130 and BAe-146 research aircraft during VOCALS-REx (Wood et al., 2010b). The in-situ aircraft observations spanned the boundary between the POC and the more overcast cloud deck. Wood et al. (2010b) show marked contrasts between the two regions in the thermodynamic structure of the boundary layer, the cloud macrostructure and in the aerosol and cloud microphysics. Persistent cloud base drizzle rates of $\sim$ several mm day ${ }^{-1}$ that are associated with the high LWP's shown in the satellite observations were observed in the surrounding overcast stratocumulus, although the majority of this drizzle evaporated in the sub-cloud boundary layer. At the POC boundary and within the POC itself strong drizzling cumulus cells were observed. A large fraction of this drizzle was observed to fall to the surface, thereby removing aerosols through precipitation scavenging and leading to lower cloud condensation nuclei and cloud droplet concentrations in the 
POC. Previous studies also show that these areas of open cells are commonly observed to contain low aerosol concentrations and exist in regions prone to drizzle (e.g. Stevens et al. (2005); Sharon et al. (2006); Wood et al. (2008)), suggesting that aerosol-cloud-drizzle interactions may play an important role in maintaining these features. High resolution cloud resolving modelling studies give further evidence that the role of precipitation and the resultant dynamical feedbacks on the boundary layer are key to both the formation and evolution of POCs e.g. Wang and Feingold (2009).

The corresponding low cloud fraction (12:00 to 13:00 UTC average) and LWP (co-incident time to satellite observations) for this case from the MetUM is shown in Fig. $11 \mathrm{~b}$ and d. It is evident that whilst the MetUM is able to capture the large synoptically driven clearing in the stratocumulus cloud to the south of the region, there is no coherent area of broken cloud that is consistent with the observed POC feature. There is a smaller area of broken cloud at $93^{\circ} \mathrm{W}, 17^{\circ} \mathrm{S}$ in the MetUM forecast (Fig. 11b), but this does not exhibit the same evolution in time as the POC, which is advected with the mean boundary layer wind to the north-west of the region over the next few days. The inability of the model to represent these regions of open cellular convection is also true of other occurrences of POCs during VOCALS-REx (not shown). The MetUM is however able to simulate the broad region of high LWP shown in the satellite observations in which the POC feature is embedded and has corresponding cloud base drizzle rates of several $\mathrm{mm} \mathrm{day}^{-1}$ as can be inferred from the LWP-drizzle relation shown in Fig. 10. It is therefore apparent that the MetUM is unable to break-up the overcast stratocumulus from drizzle alone, suggesting that key physical processes that control the transition to POCs from overcast stratocumulus are not represented in the model. Investigation of these deficiencies will be the subject of future studies utilising high resolution models.

\section{Conclusions}

We evaluate the MetUM forecast of marine stratocumulus in the southeast Pacific utilising satellite and in-situ observations from the VOCALS-REx field experiment. Marked changes in the cloud topped boundary layer occurred during the study period that were associated with large scale synoptic variability, a strong diurnal cycle in cloud and drizzle, and other inhomogeneities in the cloud field such as pockets of open cellular convection (POCs). The ability of the MetUM to represent this variability is a good test of the models description of the physical processes that control the structure and evolution of the cloud layer. The key findings are:

- There is a gradual increase in boundary layer depth from the coast to the more remote ocean. This is modulated by variability in the synoptic forcing as documented by Rahn and Garreaud (2010a,b). The MetUM is able to capture this variability although it typically exhibits a low bias of $\sim 200 \mathrm{~m}$. An exception is in the near coastal region (within $\sim 1^{\circ}$ of the shore) where the model boundary layer depth is too shallow and moist. This poor representation of the coastal marine boundary layer structure is typical of many state of the art largescale models (Wyant et al., 2010) and may be related to an insufficient representation of the mesoscale coastal circulations around the steep topography of the Andes. High resolution modelling studies in the coastal region would allow this hypothesis to be tested.

- Comparisons with satellite observations show that the MetUM has a good representation of the large scale pattern of cloud cover in the stratocumulus deck throughout the study period. An exception is along the Chilean and Peruvian coast where the observations show a large and recurrent diurnal clearing of the cloud that is not reproduced by the model. Day time cloud amounts at the coast are therefore too large in the MetUM.

- Away from the coast the diurnal cycle in cloud fraction and LWP is generally well represented in the MetUM. An exception is to the north-west of the region where the night time LWP is significantly overestimated. The MetUM also shows a marked increase in both drizzle amounts and the fraction of drizzle reaching the surface at night. However, comparisons with observed LWPdrizzle relations in the southeast Pacific suggest that the intensity of drizzle is too high in the MetUM and future analysis of VOCALS-REx observations should enable a more robust evaluation of the model drizzle intensity and sub cloud evaporation rates.

- A mode of variability in the stratocumulus deck that the MetUM is unable to simulate are POCs. Previous studies show that these areas of broken cloud tend to form in regions susceptible to heavy drizzle and are associated with low boundary layer aerosol concentrations. An example is presented from VOCALS-REx where a large POC feature is embedded in a broad region of high LWP. Whilst the model captures the area of increased LWP and has corresponding large drizzle rates it is unable to break up the cloud layer, suggesting that in the MetUM drizzle alone is not a sufficient mechanism to generate these features. It is likely that a representation of aerosol-cloud-drizzle interactions and the corresponding impacts on the mesoscale dynamics of the boundary layer are likely to be required.

To summarise, this study shows that the current version of the MetUM is able to reproduce many of the salient features of the southeast Pacific region. The model is able to forecast the general large scale features of the stratocumulus and respond to synoptic scale forcing in a realistic manner. There are however areas where the MetUM is shown to have 
consistent biases when compared against observations, such as the inability to represent the diurnal clearing of cloud in the coastal region, a systematic underestimation in cloud top height and a propensity to drizzle too efficiently.

\section{Appendix A}

\section{Microphysics formulation}

The cloud microphysics employed in the MetUM are an updated version of the scheme described by Wilson and Ballard (1999). Modifications to the scheme that are relevant to warm stratocumulus clouds such as those studied during VOCALS-REx are described below.

The model treats the cloud liquid and rain water contents as two mutually exclusive categories and it is necessary to parameterize the rate at which cloud water $\left(q_{c l}\right)$ is converted to rain water from the coalescence of cloud droplets. This is calculated using the autoconversion scheme of Tripoli and Cotton (1980), such that

$\frac{d q_{c l}}{d t}=\frac{4 \pi g E_{c} \rho^{4 / 3} q_{c l}^{7 / 3}}{18\left(\frac{4}{3} \pi\right)^{4 / 3} \mu\left(N_{d} \rho_{w}\right)^{1 / 3}}$,

where $g$ is the acceleration due to gravity, $\rho$ is the air density, $\mu$ is the dynamic viscosity of air, $\rho_{w}$ is the density of liquid water, $E_{c}$ is the coalescence efficiency of cloud droplets (assumed to be 0.55 ) and $N_{d}$ is the cloud droplet number concentration. The value of $N_{d}$ is fixed at $100 \mathrm{~cm}^{-3}$ over ocean and to $300 \mathrm{~cm}^{-3}$ over land to broadly account for changes in the amount of cloud condensation nuclei. A minimum threshold value of $q_{c l}$ is required for autoconversion to occur. The threshold is defined as the value of $q_{c l}$ at which the number concentration of cloud droplets with a radius larger than $20 \mu \mathrm{m}$ is $1000 \mathrm{~cm}^{-3}$. The particle size distribution of cloud droplets is assumed to be a modified gamma size distribution, which results in the threshold value of $q_{c l}$ ranging from $\sim 0.04 \mathrm{~g} \mathrm{~m}^{-3}$ over ocean $\left(N_{d}=100 \mathrm{~cm}^{-3}\right)$ to $\sim 0.11 \mathrm{~g} \mathrm{~m}^{-3}$ over land $\left(N_{d}=300 \mathrm{~cm}^{-3}\right)$. It should be noted that whilst Wilson and Ballard (1999) use the autoconversion rate specified by Eq. A1 a different threshold value of $q_{c l}$ at which autoconversion occurs is used.

Other modifications to the microphysics include a change to the particle size distribution of raindrops (which are assumed to be spherical) and is given by

$N_{r}(D)=n_{0} e^{-\lambda_{r} D}$,

where $N_{r}$ is the raindrop number concentration and $D$ is the diameter. $n_{0}$ is expressed as

$n_{0}=n_{a} \lambda_{r}^{n_{b}}$,

where the value of $n_{a}$ is taken to be 26.2 and $n_{b}$ is 1.57 , allowing $\lambda_{r}$ which represents the slope of the size distribution to be expressed as a function of rain rate alone, such that at lower rain rates the particle size distribution contains fewer large drops.

The fall speed relation for raindrops $V_{r}$ is also modified and is of the functional form

$V_{r}(D)=a_{r} D^{b_{r}} e^{-c_{r} D}\left(\frac{\rho_{0}}{\rho}\right)^{d_{r}}$,

where the coefficient $a_{r}$ is $386.8, b_{r}$ is $0.67, c_{r}$ is 0.0 and $d_{r}$ is 0.4 . $\rho_{0}$ is a reference density of $1 \mathrm{~kg} \mathrm{~m}^{-3}$.

Acknowledgements. GOES-10, Iquique radiosonde and C-130 aircraft observations of $N_{d}$ were provided by NCAR/EOL under sponsorship of the National Science Foundation. Data are available at http://data.eol.ucar.edu. The BAe-146 aircraft observations of $N_{d}$ were provided by the Facility for Airborne Atmospheric Measurements (FAAM). AMSR-E, SSMI and TMI data are produced by Remote Sensing Systems and sponsored by the NASA Earth Science MEaSUREs DISCOVER Project and the AMSR-E Science Team. Data are available at www.remss.com. MODIS data were obtained from the NASA LAADS data archive. D. Leon and the staff of the University of Wyoming King Air National Facility supported by grant NSF ATM-0745986 are thanked for providing the $\mathrm{C}-130$ cloud top height data. The staff of the Airborne Research and Survey Facility and H. Ricketts who is supported by NCAS are thanked for providing the Do-228 cloud top height data. We thank the scientists from the Ronald H. Brown for provision of the ship based sounding data. V. Ghate is thanked for providing the Stratus cloud fraction climatology. The authors would also like to thank P. Barrett, P. Brown, R. Wood, T. Toniazzo, A. Lock and two anonymous reviewers for their valuable discussions throughout the course of this study. This work is Crown Copyright and may not be amended in any way.

Edited by: C. R. Mechoso

\section{References}

Abel, S. J. and Shipway, B. J.: A comparison of cloud-resolving model simulations of trade wind cumulus with aircraft observations taken during RICO, Q. J. Roy. Meteorol. Soc., 133, 781794, 2007.

Albrecht, B.: Aerosols, cloud microphysics, and fractional cloudiness, Science, 245, 1227-1230, 1989.

Allen, G., Coe, H., Abel, S. J., and coauthors: Southeast Pacific atmospheric composition and variability sampled along $20^{\circ} \mathrm{S}$ during VOCALS-REx, Atmos. Chem. Phys. Discuss., in preparation, 2010.

Bony, S. and Dufresne, J. -L.: Marine boundary layer clouds at the heart of tropical cloud feedback uncertainties in climate models, Geophys. Res. Lett., 32, L20806, doi:10.1029/2005GL023851, 2005.

Bodas-Salcedo, A., Webb, M. J., Brooks, M. E., Ringer, M. A., Williams, K. D., Milton, S. F., and Wilson, D. R.: Evaluating cloud systems in the Met Office global forecast model using simulated Cloudsat radar reflectivities, J. Geophys. Res., 113, D00A13, doi:10.1029/2007JD009620, 2008.

Bretherton, C. S., Uttal, T., Fairall, C. W., Yuter, S. E., Weller, R. A., Baumgardner, D., Comstock, K., Wood, R., and Raga, G. B.: 
The EPIC 2001 stratocumulus study, B. Am. Meteorol. Soc., 85, 967-977, 2004.

Bretherton, C. S., Wood, R., George, R. C., Leon, D., Allen, G., and Zheng, X.: Southeast Pacific stratocumulus clouds, precipitation and boundary layer structure sampled along $20 \mathrm{~S}$ during VOCALS-REx, Atmos. Chem. Phys. Discuss, 10, 15921-15962, doi:10.5194/acpd-10-15921-2010, 2010.

Comstock, K. K., Wood, R., Yuter, S. E., and Bretherton, C. S.: Reflectivity and rain rate in and below drizzling stratocumulus, Q. J. Roy. Meteorol. Soc, 130, 2891-2918, 2004.

Davies, T., Cullen, M., Malcolm, A., Mawson, M., Staniforth, A., White, A., and Wood, N.: A new dynamical core for the Met Office's global and regional modelling of the atmosphere, Q. J. Roy. Meteorol. Soc, 131, 1759-1782, 2005.

Edwards, J. M. and Slingo, A.: Studies with a flexible new radiation code. I: Choosing a configuration for a large-scale model, Q. J. Roy. Meteorol. Soc, 122, 689-719, 1996.

Garreaud, R. D. and Muñoz, R. C.: The low-level jet off the west coast of subtropical South America: structure and variability, Mon. Weather. Rev., 133, 2246-2261, 2005.

Geoffroy, O., Brenguier, J. -L., and Sandu, I.: Relationship between drizzle rate, liquid water path and droplet concentration at the scale of a stratocumulus cloud system, Atmos. Chem. Phys., 8, 4641-4654, doi:10.5194/acp-8-4641-2008, 2008.

Ghate, V. P., Albrecht, B. A., Fairall, C. W., and Weller, R. A.: Climatology of surface meteorology, surface fluxes, cloud fraction, and radiative forcing over the southeast Pacific from buoy observations, J. Climate, 22, 5527-5540, 2009.

Hannay, C., Williamson, D. L., Hack, J. J., Kiehl, J. T., Olson, J. G., Klein, S. A., Bretherton, C. S., and Köhler, M.: Evaluation of forecasted Southeast Pacific stratocumulus in the NCAR, GFDL, and ECMWF models, J. Climate, 22, 2871-2899, 2009.

Hubanks, P. A., King, M. D., Platnick, S., and Pincus, R.: MODIS algorithm theoretical basis document for level-3 global gridded atmosphere products, No. ATBD-MOD-30, 2008.

Klein, S. A. and Hartmann, D. L.: The seasonal cycle of low stratiform clouds, J. Climate, 6, 1587-1606, 1993.

Lock, A. P., Brown, A. R., Bush, M. R., Martin, G. M., and Smith, R. N. B.: A new boundary layer mixing scheme. Part I: Scheme description and single-column model tests, Mon. Weather Rev., 128, 3187-3199, 2000.

Lock, A. P.: The numerical representation of entrainment in parameterizations of boundary layer turbulent mixing, Mon. Weather Rev., 129, 1148-1163, 2001.

Lock, A. P.: The sensitivity of a GCM's marine stratocumulus to cloud-top entrainment, Q. J. R. Meteorol. Soc., 130, 3323-3338, 2004.

Lorenc, A. C., Ballard, S. P., Bell, S., Ingleby, N. B., Andrews, P. L. F., Barker, D. M., Bray, J. R., Clayton, A. M., Dalby, T., Li, D., Payne, T. J., and Saunders, F. W.: The Met Office global three-dimensional variational data assimilation scheme, Q. J. R. Meteorol. Soc, 126, 2291-3012, 2000.

Ma, C.-C., Mechoso, C. R., Robertson, A. W., and Arakawa, A.: Peruvian stratus clouds and the tropical Pacific circulation: A coupled ocean-atmosphere GCM study, J. Climate, 9, 1635-1645, 1996.

Martin, G. M., Ringer, M. A., Pope, V. D., Jones, A., Dearden, C., and Hinton, T. J.: The physicsal properties of the atmosphere in the new Hadley Centre Global Environment Model, HadGEM1.
Part I: Model description and global climatology, J. Climate, 19, 1274-1301, 2006

O’Dell, C. W., Wentz, F. J., and Bennartz, R.: Cloud liquid water path from satellite-based passive microwave observations: A new climatology over the global Oceans, J. Climate, 21, 1721-1739, 2008.

Painemal, D., Garreaud, R., Rutllant, J., and Zuidema, P.: Southeast Pacific stratocumulus: High-frequency variability and mesoscale structures over San Felix Island, J. Appl. Meteorol. Clim., 49, 463-477, 2010.

Rahn, D. A. and Garreaud, R. D.: Marine boundary layer over the subtropical southeast Pacific during VOCALS-REx -Part 1: Mean structure and diurnal cycle, Atmos. Chem. Phys., 10, 4491-4506, doi:10.5194/acp-10-4491-2010, 2010.

Rahn, D. A. and Garreaud, R. D.: Marine boundary layer over the subtropical southeast Pacific during VOCALS-REx - Part 2: Synoptic variability, Atmos. Chem. Phys., 10, 4507-4519, doi:10.5194/acp-10-4507-2010, 2010.

Serpetzoglou, E., Albrecht, B. A., Kollias, P., and Fairall, C. W. Boundary layer, cloud, and drizzle variability in the southeast Pacific stratocumulus regime, J. Climate, 21, 6191-6214, 2008.

Sharon, T. M., Albrecht, B. A., Jonsson, H. H., Minnis, P., Khaiyer, M. M., van Reken, T. M., Seinfeld, J., and Flagan, R.: Aerosol and cloud microphysical characteristics of rifts and gradients in maritime stratocumulus clouds, J. Atmos. Sci., 63, 983-997, 2006.

Shipway, B. J. and Abel, S. J.: Analytical estimation of cloud droplet nucleation based on an underlying aerosol population, Atmos. Res., 96, 344-355, 2010.

Siebesma, A. P., Jakob C., Lenderink. G., Neggers, R. A. J., Teixeira, J., Meijgaard, E. Van., Calvo, J., Chlond, A., Grenier, H., Jones, C., Köhler, M., Kitagawa, H., Marquet, P., Lock, A. P., Müller, F., Olmeda, D., and Severijns, C.: Cloud representation in general-circulation models over the northern Pacific Ocean: A EUROCS intercomparison study, Q. J. Roy. Meteorol. Soc, 116, 3245-3267, 2004

Slingo, A.: Sensitivity of the earth's radiation budget to changes in low clouds, Nature, 343, 49-51, 1990.

Smith, R.: A scheme for predicting layer clouds and their watercontent in a general-circulation model, Q. J. Roy. Meteorol. Soc, 116, 435-460, 1990.

Stevens, B., Vali, G., Comstock, K., Wood, R., VanZanten, M. C., Austin, P. H., Bretherton, C. S., and Lenschow, D. H.: Pockets of open cells (POCs) and drizzle in marine stratocumulus, Bull. Am. Meteorol. Soc., 86, 51-57, 2005.

Tripoli, G. J., and Cotton, W. R.: A numerical investigation of several factors contributing to the observed variable intensity of deep convection over south Florida, J. Appl. Meteorol., 19, 1037$1063,1980$.

Turton, J. D. and Nicholls, S.: A study of the diurnal variation of stratocumulus using a multiple mixed layer model, Q. J. Roy. Meteorol. Soc., 113, 969-1009, 1987.

Twomey, S.: Pollution and the planetary albedo, Atmos. Environ., 8, 1251-1256, 1974.

Wang, H. and Feingold, G.: Modeling mesoscale cellular structures and drizzle in marine stratocumulus. Part I: Impact of drizzle on the formation and evolution of open cells, J. Atmos. Sci, 66, 3257-3275, 2009.

Wang, S., O’Neill, L. W., Jiang, Q., de Szoeke, S. P., Hong, X., Jin, 
H., Thompson, W. T., and Zheng, X.: A regional real-time forecast of marine boundary layers during VOCALS-REx, Atmos. Chem. Phys. Discuss., 10, 18419-18466, doi:10.5194/acpd-1018419-2010, 2010.

Wilson, D. R. and Ballard, S. P.: A microphysically based precipitation scheme for the Meteorological Office Unified Model, Q. J. Roy. Meteorol. Soc, 125, 1607-1636, 1999.

Wood, R.: Drizzle in boundary layer clouds. Part II: Microphysical aspects, J. Atmos. Sci., 62, 3034-3050, 2005.

Wood, R., Comstock, K. K., Bretherton, C. S., Cornish, C., Tomlinson, J., Collins, D. R., and Fairall, C.: Open cellular structure in marine stratocumulus sheets, J. Geophys. Res., 113, D12207, doi:10.1029/2007JD009371, 2008.

Wood, R., Kubar, T. L., and Hartmann, D. L.: Understanding the importance of microphysics and macrophysics for warm rain in marine low clouds. Part II: Heuristic models of rain formation, J. Atmos. Sci, 66, 2973-2990, 2009.

Wood, R., Bretherton, C. S., Mechoso, C. R., Weller, R. A., Huebert, B., Straneo, F., Albrecht, B. A., Coe, H., Allen, G., Vaughan, G., Daum, P., Fairall, C., Chand, D. Gallardo Klenner, L., Garreaud, R., Grados Quispe, C., Covert, D. S., Bates, T. S., Krejci, R., Russell, L. M., de Szoeke, S., Brewer, A., Yuter, S. E., Springston, S. R.., Chaigneau, A., Toniazzo, T., Minnis, P., Palikonda, R., Abel, S. J., Brown, W. O. J., Williams, S., Fochesatto, J., and Brioude, J.: The VAMOS Ocean-CloudAtmosphere-Land Study Regional Experiment (VOCALS-REx): goals, platforms, and field operations, Atmos. Chem. Phys. Discuss., 10, 20769-20822, doi:10.5194/acp-10-20769-2010, 2010a.
Wood, R., Bretherton, C. S., Leon, D., Clarke, A. D., Zuidema, P., Allen, G., and Coe, H.: An aircraft case study of the spatial transition from closed to open mesoscale cellular convection, Atmos. Chem. Phys. Discuss., 10, 17911-17980, doi:10.5194/acpd-1017911-2010, 2010b.

Wyant, M. C., Bretherton, C. S., Chlond, A., Griffin, B. M., Kitagawa, H., Lappen, C. -L., Larson, V. E., Lock, A., Park, S., de Roode, S. R., Uchida, J., Zhao, M., and Ackerman, A. S.: A single-column model intercomparison of a heavily drizzling stratocumulus-topped boundary layer, J. Geophys. Res., 112, D24204, doi:10.1029/2007JD008536, 2007.

Wyant, M. C., Wood, R., Bretherton, C. S., Mechoso, C. R., Bacmeister, J., Balmaseda, M. A., Barrett, B., Codron, F., Earnshaw, P., Fast, F., Hannay, C., Kaiser, J. W., Kitagawa, H., Klein, S. A., Köhler, M., Manganello, J., Pan, H. -L., Sun, F., Wang, S., and Wang, Y.: The PreVOCA experimient: modeling the lower troposphere in the Southeast Pacific, Atmos. Chem. Phys., 10, 4757-4774, doi:10.5194/acp-10-4757-2010, 2010.

Zuidema, P., Painemal, D., de Szoeke, S., and Fairall, C.: Stratocumulus cloud-top height estimates and their climatic implications, J. Climate, 22, 4652-4666, 2009. 